\title{
46. BACTERIAL BIOMASS AND ACTIVITY IN THE DEEP SEDIMENT LAYERS OF THE JAPAN SEA, HOLE 798B ${ }^{1}$
}

\author{
B. A. Cragg, ${ }^{2}$ S. M. Harvey, ${ }^{3}$ J. C. Fry, ${ }^{4}$ R. A. Herbert,${ }^{5}$ R. J. Parkes ${ }^{2}$
}

\begin{abstract}
Sediment whole-round cores from a dedicated hole (798B) were obtained for detailed microbiological analysis, down to 518 $\mathrm{m}$ below the seafloor (mbsf). These sediments have characteristic bacterial profiles in the top $6 \mathrm{mbsf}$, with high but rapidly decreasing bacterial populations (total and dividing bacteria, and concentrations of different types of viable heterotrophic bacteria) and potential bacterial activities. Rates of thymidine incorporation into bacterial DNA and anaerobic sulfate reduction are high in the surface sediments and decrease rapidly down to $3 \mathrm{mbsf}$. Methanogenesis from $\mathrm{CO}_{2} / \mathrm{H}_{2}$ peaks below the maximum in sulfate reduction and although it decreases markedly down the core, is present at low rates at all but one depth. Consistent with these activities is the removal of pore-water sulfate, methane gas production, and accumulation of reduced sulfide species. Rates of decrease in bacterial populations slow down below $6 \mathrm{mbsf}$, and there are some distinct increases in bacterial populations and activities that continue over considerable depth intervals. These include a large and significant increase in total heterotrophic bacteria below $375 \mathrm{mbsf}$, which corresponds to an increase in the total bacterial population, bacterial viability, a small increase in potential rates of sulfate reduction, and the presence of thermogenic methane and other gases. Bacterial distributions seem to be controlled by the availability of terminal electron acceptors (e.g., sulfate), the bioavailability of organic carbon (which may be related to the dark/light bands within the sediment), and biological and geothermal methane production. Significant bacterial populations are present even in the deepest samples ( $518 \mathrm{mbsf}$ ) and hence it seems likely that bacteria may continue to be present and active much deeper than the sediments studied here. These results confirm and extend our previous results of bacterial activity within deep sediments of the Peru Margin from Leg 112, and to our knowledge this is the first comprehensive report of the presence of active bacterial populations from the sediment surface to in excess of $500 \mathrm{mbsf}$ and sediments $>4$ m.y. old.
\end{abstract}

\section{INTRODUCTION}

Marine sediments play a major role in the biogeochemical cycling of elements (Jørgensen, 1983). Relative to seawater, organic matter is concentrated 10,000- to 100,000 -fold in sediments, and this material is used for energy by bacteria. As a consequence, bacteria drive the chemical cycles within the sediment. Bacteria also have a profound effect on the extent to which organic matter is degraded or preserved, and they contribute their own biomass to the organic matter ultimately preserved within deep sediments, which on maturation may produce oil and gas deposits. The importance of bacterial activity within surface sediments is now well established, as it is intimately involved in cycling of nitrogen (Sørensen, 1978), iron manganese, and sulfur (Sørensen and Jørgensen, 1987), in addition to the diagenesis of organic matter.

Indirect geochemical evidence suggests that microbial activity continues to considerable depths within the sediment (chemical changes in pore water, gas production, modification of organic complexes such as kerogen, concretion formation, and isotopic evidence; Krumbein, 1983). Temperature is unlikely to limit bacterial activity until several kilometers below the surface, as bacteria can grow in temperatures exceeding $100^{\circ} \mathrm{C}$ (Jannasch and Taylor, 1984) and the thermal gradient of the Earth's crust is approximately $10^{\circ}-40^{\circ} \mathrm{C} / \mathrm{km}$. The presence and activity of microorganisms in pristine deep subsurface environments (greater than $50 \mathrm{~m}$ below the surface) however, has not been confirmed by appropriate microbiological data (Sinclair and Ghiorse, 1989). Early research was based solely on the enrichment of viable bacteria (Rittenberg, 1940; ZoBell, 1958; Davis, 1967), with the possibilities of deep sediment layers being contaminated by the more

'Pisciotto, K. A., Ingle, J. C., Jr., von Breymann, M. T., Barron, J., et al., 1992. Proc. ODP, Sci. Results, 127/128, Pt. I: College Station, TX (Ocean Drilling Program).

${ }^{2}$ Department of Geology, University of Bristol, Bristol BS8 IRJ, United Kingdom.

${ }^{3}$ Dunstaffnage Marine Laboratory, P.O. Box 3, Oban, Argyll PA34 4AD, United Kingdom.

${ }^{4}$ School of Pure and Applied Biology, University of Wales College of Cardiff, P.O. Box 915, Cardiff CF1 3TL, United Kingdom.

${ }^{5}$ Department of Biology, Univ. of Dundee, Dundee DDHN, United Kingdom. active surface sediments. A few more recent publications have reported the detection or cultivation of bacteria from sediment depths of $200 \mathrm{~m}$ (Oremland et al., 1982; Belyaev and Ivanov, 1983; Bianchi, 1986), and low levels of anaerobic activity have been found between 4 and $167 \mathrm{~m}$ in marine sediments (Whelan et al., 1985; Tarafa et al., 1987). Extensive investigations of deep aquifers (Erlich and Ghiorse, 1989; Balkwill et al., 1989; Chapelle and Lovely, 1990; Fredrickson et al., 1991) have confirmed the presence of bacteria, and low levels of bacterial activity, in samples over $400 \mathrm{~m}$ below the surface. These data reinforce our results from deep marine sediment layers from the Peru Margin, demonstrating significant bacterial populations and activities down to $80 \mathrm{mbsf}$ (Cragg et al., 1990; Parkes et al., 1990). In this study, and those of deep aquifers (Balkwill, 1989), bacterial populations did not decrease continuously with depth, which suggests that significant microbial populations may exist to even greater depths.

We obtained intact core sections from Leg 128 in the Japan Sea from depths in excess of 500 mbsf to determine the presence of bacterial populations and activities in sediments significantly deeper than those previously investigated.

\section{MATERIALS AND METHODS \\ Shipboard Handling}

Sediment samples from Hole 798B, water depth $900 \mathrm{~m}$, were obtained between 28 and 30 August 1989. A total of 22, 25-cm whole-round cores plus one sample of $1 \mathrm{~cm}^{3}$ (Table 1) were removed from the middle of $1.5-\mathrm{m}$ core sections and the core-catcher, respectively. The section to be cut was cleaned and wiped with alcohol and then placed in a specially constructed sterile rig (Fig. 1A) and the core cut with a sterile hacksaw blade under jets of sterile oxygen-free-nitrogen (OFN) filtered through sterile $0.2 \mu \mathrm{m}$ gas filters to maintain anaerobic conditions. The cut ends were covered with a sterile metal slice and the $25-\mathrm{cm}$ whole-round core removed from the rig. The cut ends were then flamed and capped with sterile (gamma irradiated) core end-caps while gassing with a sterile OFN gassing jet to expel any air. The whole-round cores were then inserted into gas-tight anaerobic bags containing an "Anaerocult-A" sachet (Merck, Eastleigh, 
Table 1. Detailed list of Leg 128 samples provided for bacteriological examination.

\begin{tabular}{rrrr}
\hline Sample & Designation & $\begin{array}{c}\text { Interval } \\
(\mathrm{cm})\end{array}$ & $\begin{array}{c}\text { Depth } \\
(\mathrm{mbsf})\end{array}$ \\
\hline & $128-798 \mathrm{~B}-$ & & \\
1. & $1 \mathrm{H}-1$, & $0.00-0.25$ & 0.00 \\
2. & $1 \mathrm{H}-1$, & $0.25-0.50$ & 0.25 \\
3. & $1 \mathrm{H}-1$, & $0.50-0.75$ & 0.50 \\
4. & $1 \mathrm{H}-1$, & $0.75-1.00$ & 0.75 \\
5. & $1 \mathrm{H}-1$, & $1.00-1.25$ & 1.00 \\
6. & $1 \mathrm{H}-2$, & $0.10-0.35$ & 1.60 \\
7. & $1 \mathrm{H}-2$, & $1.02-1.27$ & 2.52 \\
8. & $1 \mathrm{H}-3$, & $0.75-1.00$ & 3.75 \\
9. & $1 \mathrm{H}-4$, & $1.00-1.25$ & 5.50 \\
10. & $2 \mathrm{H}-1$, & $0.20-0.45$ & 9.60 \\
11. & $2 \mathrm{H}-3$, & $0.20-0.45$ & 12.60 \\
12. & $3 \mathrm{H}-4$, & $0.60-0.85$ & 23.50 \\
13. & $4 \mathrm{H}-7$, & $0.31-0.56$ & 36.71 \\
14. & $6 \mathrm{H}-4$, & $0.22-0.47$ & 51.02 \\
15. & $9 \mathrm{H}-3$, & $0.80-1.05$ & 78.70 \\
16. & $14 \mathrm{H}-7$, & $0.98-1.23$ & 133.18 \\
17. & $21 \mathrm{X}-2$, & $0.20-0.45$ & 192.70 \\
18. & $27 \mathrm{X}-3$, & $0.80-1.05$ & 252.80 \\
19. & $36 \mathrm{X}-2$, & $0.40-0.65$ & 336.50 \\
20. & $40 \mathrm{X}-2$, & $0.45-0.70$ & 375.15 \\
21. & $45 \mathrm{X}-3$, & $0.35-0.60$ & 424.85 \\
22. & $53 \mathrm{X}-4$, & $0.25-0.50$ & 503.45 \\
23. & $54 \mathrm{X}-\mathrm{CC}$ & $1 \mathrm{~cm}$ & 517.90 \\
\hline & & & \\
\hline
\end{tabular}

U.K.) to remove all oxygen, and sealed with a modified impulse bag-sealer (Jencons, Leighton Buzzard, U.K.). Samples were temporarily stored in the ship cold room at $4^{\circ} \mathrm{C}$.

For Samples 1-5 (Table 1) prior to sealing, a 1- $\mathrm{cm}^{3}$ sample was taken for "fresh" direct bacterial counts, from the lower end of the whole-round core, using a sterile (autoclaved) $5-\mathrm{mL}$ syringe with the leur end removed, and stored in a serum vial containing $9 \mathrm{~mL}$ of filter-sterilized $(0.2 \mu \mathrm{m}) 4 \%$ formaldehyde in artificial seawater. On Samples 6-22 the 1- $\mathrm{cm}^{3}$ sample was taken from the cut end adjacent to the lower part of the $25-\mathrm{cm}$ whole-round core, after flaming the end.

A $6-\mathrm{cm}$ whole-round core was then removed from the adjacent sediment for extraction of pore-water for chemical analysis. After squeezing in the ships' rig, subsamples were either stored in sealed vials in the freezer, or preserved for sulfate and sulfide analyses $(4 \mathrm{~mL}$ in $1 \mathrm{~mL}$ of $10 \%$ zinc acetate) before being refrigerated.

\section{Ship - Laboratory Transportation}

The whole-round cores for microbiological analysis were transported from JOIDES Resolution by Cragg and Parkes on 3 September 1989 aboard a Japanese tugboat, Nippon Maru. They were stored in a commercial refrigerator at $5^{\circ} \mathrm{C}$ on board for the 2.5 -day journey to Moji, Japan, where they were packed into a large, insulated, prechilled (dry ice) aluminum trunk with "Igloo" freezer packs. The trunk was customs-sealed and transported by air to the laboratory. On arrival ( 7 September) the trunk contents were transferred to a cold room at $4^{\circ} \mathrm{C}$. During transportation the samples had remained cold.

The samples of frozen sediment and the frozen pore-water samples remained on board the JOIDES Resolution and were forwarded to our laboratory (packed in dry ice) from ODP in April 1990.

\section{Laboratory Handling}

\section{Whole-Round Cores}

\section{Initial Handling}

The sealed whole-round cores were opened in the laboratory on 19 September 1989 ( 3 weeks after they had been taken). All primary handling and subsequent subsampling was conducted at $16^{\circ} \mathrm{C}$ under sterile nitrogen jets and aseptic techniques in a laminar flow cabinet. The $25-\mathrm{cm}$ whole-round cores were divided into sequential $5 \times 5-\mathrm{cm}$ sections. For the upper samples this was done by uncapping both ends of

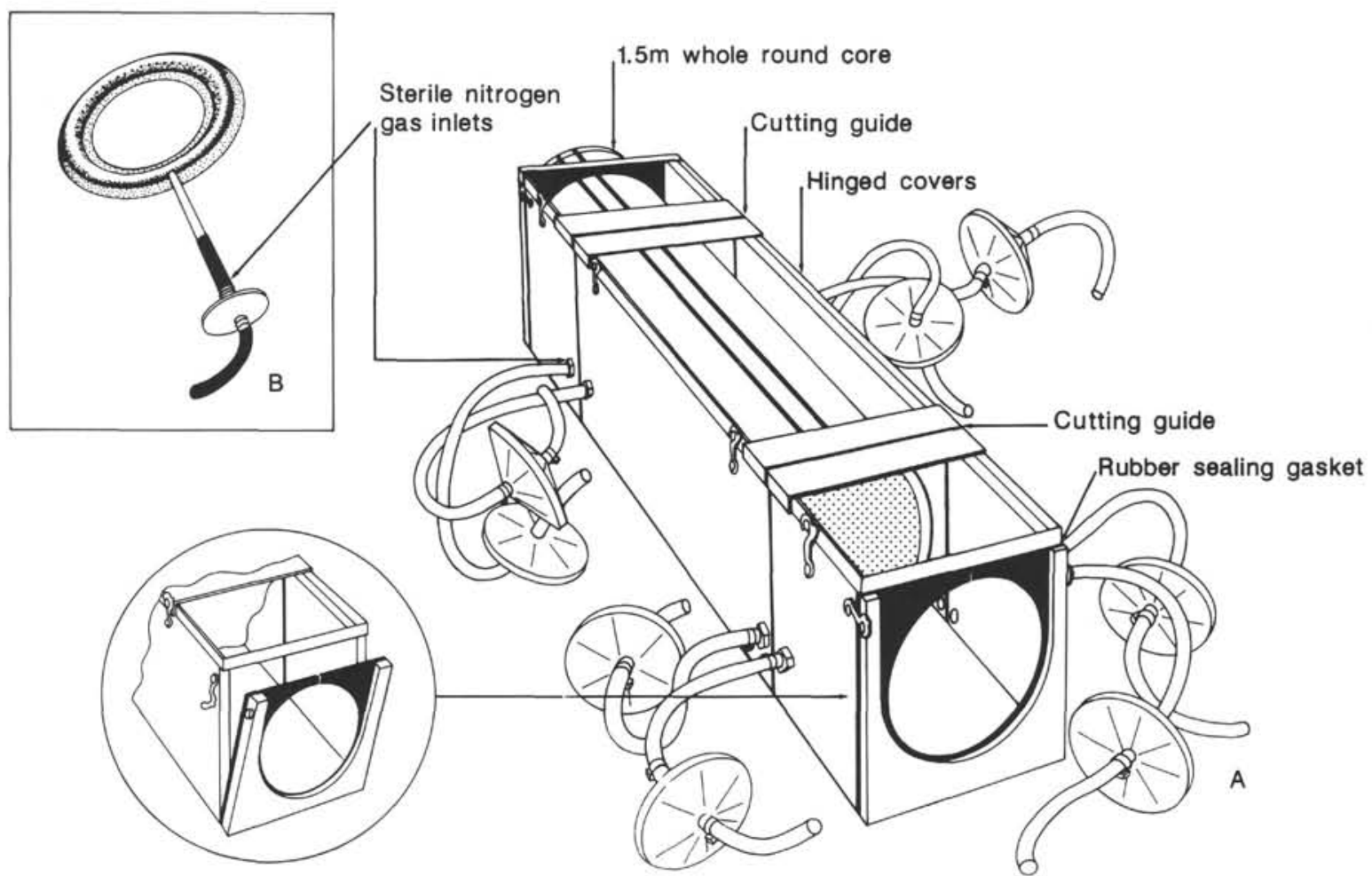

Figure 1. A. Cutting rig designed to remove sections of core under sterile and anaerobic conditions. B. Gassing jet designed to provide a constant stream of oxygen-free nitrogen over sections of whole-round core during subcoring. 
the core, and briefly flaming them before extruding $5-\mathrm{cm}$ sediment sections into sterile polycarbonate sleeves using a sterile stepped plunger inserted into the base of the whole-round core. Each $5-\mathrm{cm}$ section was removed by slicing through the core with a sterile slice. For the middle and lower samples, where the sediment was more compacted, the plunger system of core extraction proved inadequate, and 5-cm whole-round cores were cut using the core-cutting apparatus described above.

\section{Subsampling}

Each 5-cm whole-round core was assigned to a particular activity measurement, together with the relevant most-probable-number (MPN) viable count of specific bacterial types, direct counts, and some additional measurements (Table 2). Within each 5 -cm whole-round core, subcores were taken using sterile (autoclaved) 5-mL plastic syringes (Beckman-Dickinson, Oxford, U.K.) from which the leur end had been removed. Volumes taken were $10 \times 5 \mathrm{~cm}^{3}$ (activity measurements), $2 \times 5 \mathrm{~cm}^{3}$ (MPN and direct counts), $2 \times 5 \mathrm{~cm}^{3}$ (porosity) and $2 \times 5 \mathrm{~cm}^{3}$ (pore-water analysis). During subcoring a flow of sterile OFN was maintained across the surface of the whole-round core from a gassing rig consisting of a copper ring with inwardly facing jets mounted on a circular flange that rested on the polycarbonate sleeve-edge (Fig. 1B). Sediment adjacent to the core liner was not sampled. Syringe subcores were sealed with sterile butyl rubber "Suba Seals" (Wm. Freeman and Co. Ltd., Barnsley, U.K.) and either (1) stored for a few hours (MPN), or overnight (activity measurement) in anaerobic jars at $16^{\circ} \mathrm{C}$, (2) centrifuged for chemical porewater analysis, or (3) dealt with immediately (porosity). Sediment subcores were replaced by sterile perspex pegs of the same size to enable the remaining sediment to be sampled intact. Sterile disposable gloves were used during handling aboard ship and in the laboratory.

\section{Potential Activity Measurements}

\section{Sample Handling}

Three isotopes were separately injected into the syringe subcores using a glass microsyringe and special rig that allowed steady injection of isotope along the center line of the subcore. Each group of 10 subcores was divided into 1 time-zero control and $3 \times$ three incubation periods. Those requiring incubation were sealed in anaerobic bags as described above, and incubated at $16^{\circ} \mathrm{C}$ mean downhole temperature for various periods (Table 3 ). Incubation was terminated by placing the bags into a freezer at $-20^{\circ} \mathrm{C}$ where they were stored until analyzed. Subcores for time-zero control were pre-chilled $\left(4^{\circ} \mathrm{C}\right)$, injected, and immediately frozen $\left(-20^{\circ} \mathrm{C}\right)$, and then sealed in anaerobic bags and stored frozen.

\section{Isotope Preparation}

All isotopes were obtained from Amersham International (Amersham, U.K.). They were diluted with autoclaved distilled water and membrane filter sterilized $(0.2 \mu \mathrm{m})$ into a number of glass vials. Both ${ }^{14} \mathrm{C}$ sodium bicarbonate and ${ }^{3} \mathrm{H}$-thymidine were stored at $4^{\circ} \mathrm{C}$, and the ${ }^{35} \mathrm{~S}$-sulfate was stored at $-20^{\circ} \mathrm{C}$. The ${ }^{3} \mathrm{H}$-methyl thymidine was supplied as a sterile solution containing $2 \%$ ethanol. This solution was hand warmed and the ethanol blown off using a sterile OFN gassing jet prior to use. Injections into the syringe cores were: ${ }^{35} \mathrm{SO}_{4} 7.2 \mu \mathrm{L}=$ $2.28 \mu \mathrm{Ci}$ (sulfate reduction); $\mathrm{H}^{14} \mathrm{CO}_{3} 7.2 \mu \mathrm{L}=3.77 \mu \mathrm{Ci}$ (methanogenesis and acetogenesis); ${ }^{3} \mathrm{H}$-methyl thymidine $32 \mu \mathrm{L}=14.7 \mu \mathrm{Ci}$ (thymidine incorporation).

\section{Measurement of Activity}

Rates of sulfate reduction were determined from the proportion of ${ }^{35} \mathrm{~S}$-labeled sulfide produced from the ${ }^{35} \mathrm{~S}$-sulfate injected. Sulfide
Table 2. Breakdown of microbiological measurements made on each of the $5-\mathrm{cm}$ core sections obtained from a $25-\mathrm{cm}$ whole-round core.

\begin{tabular}{|c|c|c|c|}
\hline $\begin{array}{l}\text { Core } \\
\text { section } \\
(\mathrm{cm})\end{array}$ & $\begin{array}{l}\text { Activity } \\
\text { measurement }\end{array}$ & $\begin{array}{l}\text { Bacterial } \\
\text { count }\end{array}$ & Other \\
\hline $1-5$ & $\begin{array}{l}\text { Sulfate } \\
\text { reduction }\end{array}$ & $\begin{array}{l}\text { MPN SO }_{4}{ }^{2-} \text { reducers } \\
\text { (acetate and lactate) } \\
\text { Direct count }\end{array}$ & $\begin{array}{l}\text { Porosity } \\
\mathrm{SO}_{4}^{2-} \& \mathrm{~S}^{-} \\
\text {analysis }\end{array}$ \\
\hline $5-10$ & $\begin{array}{l}\text { Methane } \\
\text { production }\end{array}$ & $\begin{array}{l}\mathrm{MPN} \mathrm{CH}_{4} \text { producers } \\
\text { Direct count }\end{array}$ & Porosity \\
\hline $10-15$ & $\begin{array}{l}\text { Acetate } \\
\text { production }\end{array}$ & MPN acetogens & Porosity \\
\hline $15-20$ & & $\begin{array}{l}\text { MPN } \mathrm{NO}_{3}^{-} \text {reducers } \\
\mathrm{MPN} \mathrm{NH}_{4}^{+} \text {producers } \\
\text { (aerobic and anaerobic) } \\
\text { MPN Heterotrophs } \\
\text { Direct count }\end{array}$ & Porosity \\
\hline $20-25$ & $\begin{array}{l}\text { Thymidine } \\
\text { incorporation }\end{array}$ & Direct count & Porosity \\
\hline
\end{tabular}

distillation and radioactive counting was as described by Parkes and Buckingham (1986) and both acid-volatile-sulfide (AVS) and pyrite plus sulfur (PVS) fractions determined. Methanogenic activity was calculated from the amount of ${ }^{14} \mathrm{CH}_{4}$ produced. This was oxidized to ${ }^{14} \mathrm{CO}_{2}$ and counted by liquid scintillation as described in Cragg et al. (1990). Estimates of thymidine incorporation were made following an extraction procedure based on the protocols of Karl (1982), Craven and Karl (1984), and Carmen et al. (1988) (Fig. 2). Daily activity rates were independently calculated for each of the incubation periods after subtraction of any DPM counts obtained from the respective timezero incubations (sulfate reduction mean DPM $=314$; methanogenesis mean DPM = 32; thymidine incorporation mean DPM = 1956). Rates of sulfate reduction and methane production were calculated from the activity rates, the concentrations of pore-water sulfate and alkalinity respectively, and sediment porosity (Jørgensen, 1978).

\section{Counts of Viable Bacteria}

An MPN technique (Colwell, 1979) was used to estimate numbers of viable bacteria. This involved between 5 and 10 dilution levels starting with the sediment and descending serially by either triplicate or quadruplicate 1:5 dilutions.

\section{Preparation of MPN Vials}

All MPN enrichments were performed in $7 \mathrm{~mL}$ hypovials sealed with butyl rubber septa and aluminum caps (Pierce and Warriner, Chester, U.K.). Hypovials for the serial dilutions were $30 \mathrm{~mL}$ in size and contained $20 \mathrm{~mL}$ of medium. A full description of vial preparation is given by Cragg et al., (1990).

\section{Dispensing System}

The medium-dispensing system consisted of a $30-\mathrm{mL}$ plastic syringe joined via a leur-lock to a plastic three-way stopcock which was in turn connected to a second three-way stopcock (Gallenkamp, Loughborough, U.K.) and then to a syringe needle. The upper stopcock side-arm was connected to a pressurized medium-container and the lower stopcock side-arm, via a sterile $0.2 \mu \mathrm{m}$ gas filter, to a low-pressure gas supply (either $\mathrm{N}_{2}(80 \%) / \mathrm{CO}_{2}(20 \%)$ or $\mathrm{H}_{2}(80 \%)$ / $\mathrm{CO}_{2}(20 \%)$, depending on media type). By controlling medium and gas flow with the stopcocks, evacuated $7-\mathrm{mL}$ vials were first filled 
Table 3. Incubation periods (days) for potential activity measurements, zero and three incubation times for each sample. The samples were divided into four groups based on depth and anticipated activity rates.

\begin{tabular}{|c|c|c|c|c|c|}
\hline \multicolumn{6}{|c|}{ Length of incubation period (days) } \\
\hline Sample & $\begin{array}{l}\text { Depth } \\
\text { (mbsf) }\end{array}$ & $\begin{array}{l}\text { Sulfate } \\
\text { reduction }\end{array}$ & Methanogen & Acetogen & $\begin{array}{l}\text { Thymidine } \\
\text { incorporation }\end{array}$ \\
\hline 1 & 0.00 & 0.00 & 0.00 & 0.00 & 0.00 \\
\hline 2 & 0.25 & 0.50 & 0.50 & 0.50 & 0.17 \\
\hline 3 & 0.50 & 1.00 & 1.03 & 1.00 & 0.33 \\
\hline 4 & 0.75 & 1.50 & 1.50 & 1.50 & 0.50 \\
\hline 5 & 1.00 & & & & \\
\hline 6 & 1.60 & & & & \\
\hline 7 & 2.52 & 0.00 & 0.00 & 0.00 & 0.00 \\
\hline 8 & 3.75 & 1.00 & 1.00 & 1.00 & 0.50 \\
\hline 9 & 5.50 & 5.00 & 5.00 & 5.00 & 1.00 \\
\hline 10 & 9.60 & 12.00 & 12.00 & 12.00 & 1.50 \\
\hline 11 & 12.60 & & & & \\
\hline 12 & 23.50 & 0.00 & 0.00 & 0.00 & 0.00 \\
\hline 13 & 36.71 & 3.00 & 3.00 & 3.00 & 1.01 \\
\hline 14 & 51.02 & 15.00 & 15.00 & 15.00 & 2.00 \\
\hline 15 & 78.70 & 24.00 & 24.00 & 24.00 & 3.00 \\
\hline 16 & 133.18 & & & & \\
\hline 17 & 192.70 & 0.00 & 0.00 & 0.00 & 0.00 \\
\hline 18 & 252.80 & 5.00 & 5.00 & 5.00 & 1.06 \\
\hline 19 & 336.50 & 20.00 & 20.00 & 20.00 & 3.19 \\
\hline 20 & 375.15 & 35.13 & 35.22 & 35.18 & 5.21 \\
\hline 21 & 424.85 & & & & \\
\hline 22 & 503.45 & \multicolumn{4}{|c|}{ not measured } \\
\hline 23 & 517.90 & \multicolumn{4}{|c|}{ not measured } \\
\hline
\end{tabular}

with $5 \mathrm{~mL}$ of sterile media and then pressured to slightly above ambient with gas. The tops of the septa were smeared with a silicone rubber sealant to improve the physical integrity of the seal and hence help prevent leakage through the pierced septum. Those used for detecting lactate-utilizing sulfate-reducing bacteria (SRB) were not smeared with sealant because the acetate present in the sealant might have diffused into the media.

\section{Preparation of Media}

All media contained $\mathrm{NaCl}$ and $\mathrm{MgCl}_{2}$ in quantities approximating in-situ salinities of Hole 798B ( 32 and $5 \mathrm{~g} / \mathrm{dm}^{3}$ respectively). A detailed description for the preparation of media to detect acetate and lactate $\mathrm{SRB}$, methanogens, and nitrate respirers, together with the diluent medium is given in Cragg et al., (1990). The medium described for viable heterotrophs was further modified by the addition of two extra carbon sources; chitin and cellulose, both at $0.5 \mathrm{~g} / \mathrm{dm}^{3}$ added to the hypovials prior to sterilization.

Acetogens were enriched in Widdel's marine media (Pfennig et al., 1981) as modified in Cragg et al. (1990) for enrichment of methanogens, with the further modifications of omitting cysteine, but adding casamino acids $\left(0.1 \mathrm{~g} / \mathrm{dm}^{3}\right)$ and a $\mathrm{pH}$ indicator-Bromocresol green $\left(0.15 \mathrm{~g} / \mathrm{dm}^{3}\right)$ prior to autoclaving, and the omission of both methylamine and acetate after autoclaving.

Ammonifying bacteria were enriched using Crossley Milk Medium (Oxoid, Basingstoke, U.K.) supplemented with $3 \% \mathrm{wt} / \mathrm{vol} \mathrm{NaCl}$. Aerobic ammonifying bacteria were differentiated from anaerobic ammonifiers by incubating a duplicate set of samples in screw cap vials lined with a thin silicone rubber septum which allowed gas exchange.

All media were dispensed some weeks prior to inoculation and all vials that were not reduced (pink color due to resazurin) were discarded. Resazurin was not present in the medium for enriching ammonifiers. Any potential bacterial contamination in the media would have developed during this period, however none was observed.

\section{Inoculation and Incubation Procedures}

Initial manipulations were performed in an anaerobic cabinet that had been sterilized by swabbing with an antiseptic-Hibitane (ICI, Macclesfield, U.K.) at $0.5 \%$ in $70 \%$ ethanol, followed by $1 \mathrm{hr}$ under ionizing UV light. One 5 -mL syringe subcore was ejected into the first diluent vial, which was mixed and successively diluted $(5 \mathrm{~mL}$ into $20 \mathrm{~mL}$ ). For the zero dilution level a $1-\mathrm{mL}$ sample of sediment was extruded directly into one $7-\mathrm{mL}$ hypovial. The dilution vials were removed from the anaerobic cabinet and the contents from each dilution level dispensed, using sterile 20 -mL syringes preflushed with OFN, in 1-mL aliquots into the 7-mL hypovials. All vials, apart from those used to enrich lacate-utilizing SRB were again smeared with silicone rubber sealant. Incubation was at $16^{\circ} \mathrm{C}$ and vials were checked weekly for growth.

Presumptive growth was detected by media blackening for SRB, acid and/or gas production for nitrogen reducers, direct microscopic counting for viable heterotrophs, headspace methane for methanogens and indicator color change for acetogens and both groups of ammonifiers. Viable counts and confidence limits were calculated according to Hurley and Roscoe (1983), and any vials that became oxidized after inoculation were not included in the MPN calculations.

\section{Detection of Methane}

Headspace gases were analyzed by gas chromatography (Parkes and Taylor, 1985). Vials were repressurized to 2 bars with $\mathrm{H}_{2} / \mathrm{CO}_{2}$ and smeared with sealant before incubation was resumed.

\section{Detection of Nitrate Reduction}

Using subsets of the nitrate reducer vials, the removal of nitrate and the presence/absence of nitrite was assessed with a nitrate reduction test (Cruikshank et al., 1975), and the presence/absence of 


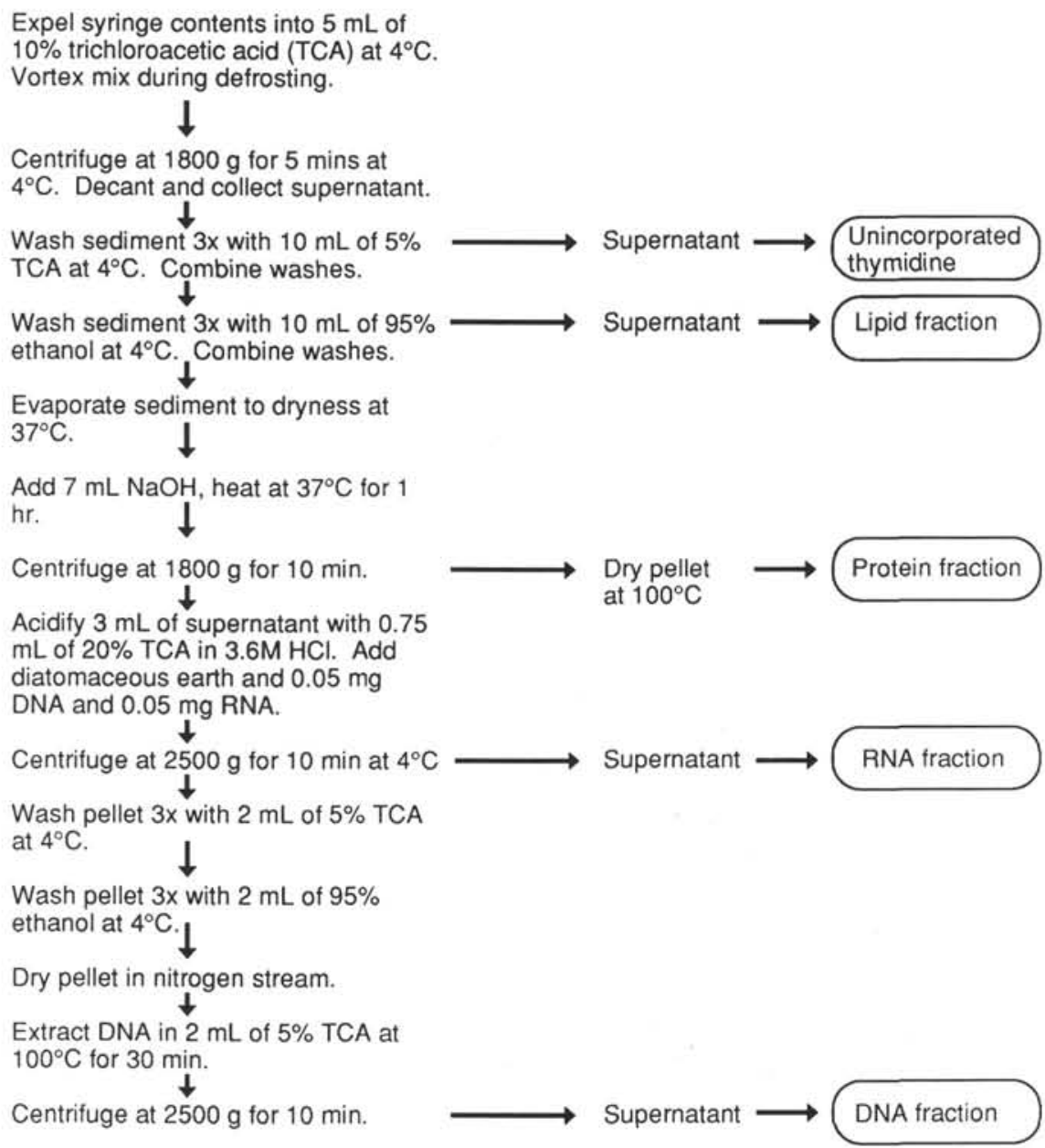

Figure 2. Protocol for the extraction of ${ }^{3} \mathrm{H}$-labeled DNA from bacteria in sediments. Based on the methods of Karl (1982), Craven and Karl (1984), and Carmen et al. (1988).

ammonium was determined with an indophenol blue colorimetric test (Golterman et al., 1978).

\section{Direct Microscopic Observation}

Direct counts were made of bacteria from each sediment depth using the Acridine Orange technique following the general recommendations of Fry (1988). A full description is given in Cragg et al. (1990). Using this method a count was made of both total bacterial cells and those involved in cell division. The latter were either cells with a clear invagination, or pairs of cells of identical morphology, and these were counted as one and two cells, respectively, in the total bacterial count.

\section{Chemical Analyses}

Pore-water sulfate was determined by means of ion chromatography (Dionex, Sunnyvale, CA, U.S.A.) using an AS4A separator column, anion micromembrane suppressor, and a bicarbonate eluent, on both pore waters obtained aboard ship and in the laboratory. Sulfide, AVS, and PVS concentrations were determined colorimetrically (Cline, 1969).

Organic carbon values were obtained from shipboard data (Ingle, Suyehiro, von Breymann, et al., 1990). As our sampling procedure removed entire core sections there were no coincident data, and an average of all adjacent $( \pm 2.5 \mathrm{~m}$ around our sample) organic carbon concentrations was calculated.

\section{RESULTS}

It was evident that the special procedures adopted during shooting of the first core of Hole 798B (Ingle, Suyehiro, von Breymann, et al., 1990) had successfully recovered much of the sediment close to the sediment/water interface, as intended. Best estimates, obtained from pollen analysis (L. Heusser, pers. comm., 1991), suggest that a maximum of only $60 \mathrm{~cm}$ was missing from the top of the core. Although this is important microbiologically, for clarity, the official ODP depths have been used throughout this paper.

\section{Direct Counts}

Bacteria are present at all depths to $517.90 \mathrm{mbsf}$ (Fig. 3). There is an initial rapid decline in numbers from $1.37 \times 10^{9} \mathrm{cells} / \mathrm{cm}^{3}$ at 0.025 mbsf to $1.9 \times 10^{8}$ cells $/ \mathrm{cm}^{3}$ at $0.075 \mathrm{mbsf}$ (seven-fold decrease). This is followed by a more gradual logarithmic decline to $1.11 \times 10^{7}$ cells $/ \mathrm{cm}^{3}$ at $517.90 \mathrm{mbsf}$ representing an overall 120 -fold decrease. Against this background of overall decrease in bacterial numbers there are some distinct increases that continue over considerable depth intervals, for example at 10,50 , and 200 mbsf. The detection limit using this procedure was $10^{5} \mathrm{cells} / \mathrm{cm}^{3}$ and the minimum count recorded was $8.10 \times 10^{5}$ cells $/ \mathrm{cm}^{3}$ at $503.67 \mathrm{mbsf}$, an almost 1700fold decrease from the near-surface count. Numbers of dividing cells declined at a similar rate to the total bacterial count, with a rapid decrease from $1.15 \times 10^{8}$ cells $/ \mathrm{cm}^{3}$ at $0.025 \mathrm{mbsf}$ to $1.19 \times 10^{7} \mathrm{cells} / \mathrm{cm}^{3}$ at $0.075 \mathrm{mbsf}$, a 10 -fold decrease (Fig. 4). Below 2 mbsf the decline 
was more gradual, to approximately $3 \times 10^{6}$ cells $/ \mathrm{cm}^{3}$ around 500 mbsf (in samples where dividing cells were observed), representing a more than a 40 -fold decrease over near-surface counts. The number of samples that contained no detectable dividing cells increased with depth. These data have been assigned the detection limit of $10^{5} \mathrm{cells} / \mathrm{cm}^{3}$. Over the complete depth range dividing cells represented, on average, $4.8 \%$ (range $0.5 \%-12.3 \%$ ) of the direct count (Figs. 3 and 4 ). Direct counts and dividing cell counts, on fresh samples taken aboard ship, showed no overall significant difference $(p=0.11$ and $p=0.40$, respectively; $n=21$ ) to stored samples taken during laboratory handling. However, as all other data were obtained from stored sediment samples, only those data are presented here.

\section{Viable Counts (Table 4 and Fig. 5)}

Aerobic ammonifying bacteria are present in low numbers, $3.19 \times 10^{2}$ bacteria/ $\mathrm{cm}^{3}$ at $0.175 \mathrm{mbsf}$ (Fig. $5 \mathrm{~A}$ ), and decline rapidly to zero by 3.92 mbsf. Occurrence below this depth is limited, with minor rises between 3.92 and $23.67 \mathrm{mbsf}, 36.8$ and $133.3 \mathrm{mbsf}$, and at $503.6 \mathrm{mbsf}$ ( 3 bacteria $/ \mathrm{cm}^{3}$ ). Anaerobic ammonifying bacteria are more numerous, with $2.72 \times 10^{4}$ bacteria/ $\mathrm{cm}^{3}$ at $0.175 \mathrm{mbsf}$ (Fig. 5D), and although numbers decline in a similarly rapid way to the aerobic ammonifiers, the bacteria are present in all samples except at 133.33 mbsf, with small rises at 78.9 and 192.9 mbsf. Between 336.7 and 503.6 mbsf there is a significant ( $p$ $<0.05$ ), increase in numbers to 117 bacteria/ $\mathrm{cm}^{3}$.

Nitrate-reducing bacteria were present at all depths (Fig. 5B). Numbers are constant at approximately 150 bacteria $/ \mathrm{cm}^{3}$ down to $1.77 \mathrm{mbsf}$ and then, after a decline, remain constant at approximately 11 bacte$\mathrm{ria} / \mathrm{cm}^{3}$. After this there was a significant $(p<0.05)$ increase to 31 bacte$\mathrm{ria} / \mathrm{cm}^{3}$ at $503.6 \mathrm{mbsf}$. As the presence of nitrate-reducing bacteria is only presumptive, a subset of the MPN vials were chemically tested for

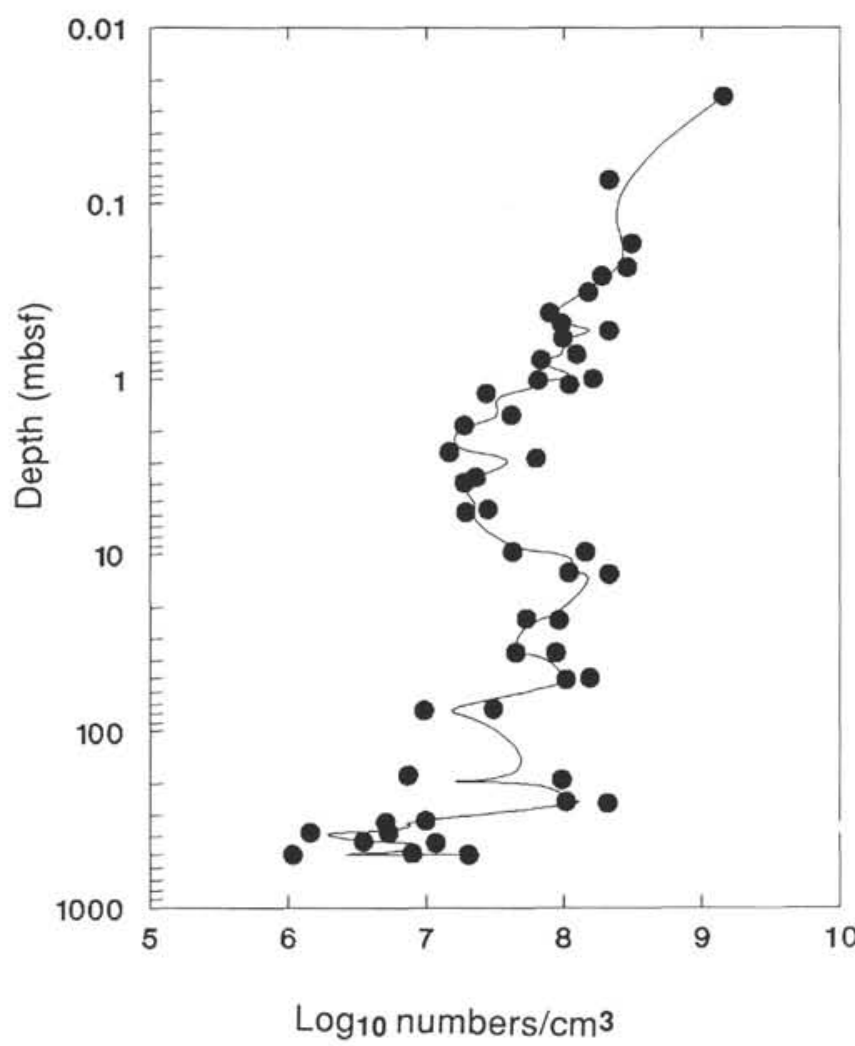

Figure 3. Depth distribution of total bacteria using the Acridine Orange Direct Count (AODC) technique to $517.90 \mathrm{mbsf}$ (line is compter-generated best-fit for the data).

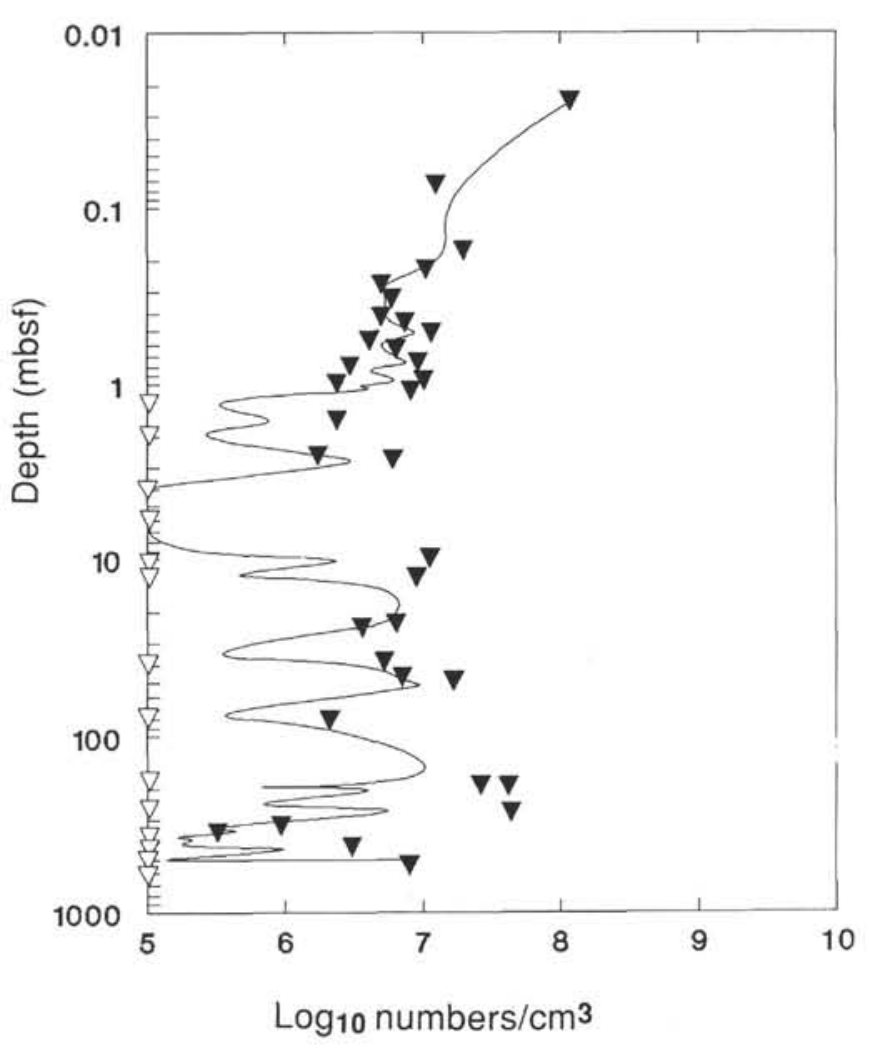

Figure 4. Depth distribution of dividing and divided bacterial cells using the AODC technique to $517.90 \mathrm{mbsf}$. Open symbols indicate zero counts that have been given the nominal value of the detection limit of $10^{5} \mathrm{cells} / \mathrm{cm}^{3}$ (line is computer-generated best-fit for the data).

reduced nitrogen species. The removal of nitrate, together with the presence of nitrite or ammonium, confirmed that active nitrate reduction is indeed taking place. The absence of all three nitrogen compounds in positive MPN vials indicates that nitrate was reduced to nitrogen gas. As these chemical tests were conducted on a subset of the vials it is not possible to give an accurate MPN for the different types of nitrate-metabolizing bacteria. However, bacteria that reduce nitrate to ammonium were not detected below $1.77 \mathrm{mbsf}$.

SRB that separately utilize acetate and lactate showed very similar profiles (Table 4) and are presented here as combined data (Fig. 5C). The highest counts of $3.4 \times 10^{4}$ bacteria/ $\mathrm{cm}^{3}$ occurred at $0.125 \mathrm{mbsf}$ and there was a gradual decline to $1.1 \times 10^{3}$ bacteria $/ \mathrm{cm}^{3}$ at $1.72 \mathrm{mbsf}$ before a rapid decline to zero. An increase in numbers of both acetate-, and lactate-utilizing SRB was present between 3.77 and $23.5 \mathrm{mbsf}$, and a single positive vial from the acetate-utilizing bacteria occurred at 78.7 mbsf (Table 4).

The presence of acetogens was indicated by a $\mathrm{pH}$ change and therefore results are presumptive. They are present in low numbers at all depths (Fig. 5E). Near the surface (0.125-2.64 mbsf) numbers averaged 360 bacteria/ $\mathrm{cm}^{3}$, with a peak of $1.1 \times 10^{3}$ bacteria/ $\mathrm{cm}^{3}$ at $1.72 \mathrm{mbsf}$ (Table 4). Below 2.64 mbsf counts averaged 40 bacteria $/ \mathrm{cm}^{3}$ with small, insignificant decreases at 36.8 and an increase toward the bottom of the core between 336.6 and 503.6 mbsf.

Viable anaerobic heterotrophs occurred in the greatest numbers of all groups counted, with an average of $5.3 \times 10^{4}$ bacteria $/ \mathrm{cm}^{3}$ between 0.175 and 9.77 mbsf, and two significant $(p<0.05)$ increases to $4.2 \times 10^{5}$ and $2.9 \times 10^{4}$ bacteria/ $\mathrm{cm}^{3}$ at 0.675 and $9.77 \mathrm{mbsf}$, respectively (Fig. 5F). Counts then declined to near zero with a significant $(p<0.05)$ peak of 114 bacteria/ $/ \mathrm{cm}^{3}$ at $78.9 \mathrm{mbsf}$ and a progressive, and very highly significant $(p<0.01)$ increase from 336.7 to 503.5 mbsf, peaking at $1.26 \times 10^{4} \mathrm{bacteria} / \mathrm{cm}^{3}$. 
Table 4. Distribution of bacterial populations in sediment to $503.57 \mathrm{mbsf}\left(\log _{10}\right.$ numbers $\left./ \mathrm{cm}^{3}\right)$.

\begin{tabular}{|c|c|c|c|c|c|c|c|c|c|c|}
\hline $\begin{array}{l}\text { Sample } \\
\text { Depth } \\
\text { (mbsf) }\end{array}$ & $\begin{array}{c}\text { (a) } \\
\text { Aerobic } \\
\text { ammonifiers }\end{array}$ & $\begin{array}{c}\text { (b) } \\
\text { Anaerobic } \\
\text { ammonifiers }\end{array}$ & $\begin{array}{c}\text { (c) } \\
\text { Nitrate } \\
\text { reducers }\end{array}$ & $\begin{array}{c}\text { (d) } \\
\text { Sulfate } \\
\text { reducers } \\
\text { (acetate) }\end{array}$ & $\begin{array}{c}\text { (e) } \\
\text { Sulfate } \\
\text { reducers } \\
\text { (lactate) }\end{array}$ & $\begin{array}{c}\text { (f) } \\
\text { Acetogens }\end{array}$ & $\begin{array}{c}\text { (g) } \\
\text { Heterotrophs }\end{array}$ & $\begin{array}{c}\text { (h) } \\
\text { Total } \\
\text { anaerobic }\end{array}$ & $\begin{array}{c}\text { (i) } \\
\text { Mean AODC } \\
\text { cells } / \mathrm{cm}^{3}\end{array}$ & $\begin{array}{c}\text { (j) } \\
\text { Anaerobic } \\
\text { viability } \\
\text { (\% of } A O D C)\end{array}$ \\
\hline $0.00-0.25$ & 319 & 27,200 & 184 & 27,600 & 6400 & 263 & 49,600 & 111,247 & $272,521,016$ & 0.0408 \\
\hline $0.25-0.50$ & 57 & 4500 & 158 & 756 & 1275 & 700 & 1950 & 9339 & $113,240,036$ & 0.00825 \\
\hline $0.50-0.75$ & 59 & 17,000 & 188 & 273 & 4225 & 117 & 416,000 & 437,803 & $77,019,377$ & 0.568 \\
\hline $0.75-1.00$ & 18 & 1125 & 188 & 45 & 120 & 117 & 3150 & 4745 & $78,749,898$ & 0.00603 \\
\hline $1.60-1.85$ & 5 & 350 & 117 & 925 & 188 & 1125 & 4150 & 6855 & $30,549,211$ & 0.0224 \\
\hline $2.52-2.77$ & 1 & 10 & 13 & 0 & 1 & 117 & 1962 & 2103 & $46,131,757$ & 0.00456 \\
\hline $3.75-4.00$ & 0 & 1 & 13 & 0 & 0 & 53 & 3750 & 3823 & $19,319,683$ & 0.0198 \\
\hline $5.50-5.75$ & 1 & 2 & 13 & 1 & 0 & 59 & 184 & 259 & $30,338,912$ & 0.000854 \\
\hline $9.60-9.85$ & NR & NR & 7 & 1 & 3 & 59 & 28,600 & 28,670 & $83,945,999$ & 0.0342 \\
\hline $12.60-12.85$ & 2 & 1 & 10 & 1 & 1 & 59 & 1 & 73 & $131,219,990$ & 0.0000556 \\
\hline $23.50-23.75$ & 0 & 1 & 10 & 0 & 0 & 59 & 1 & 71 & $39,627,803$ & 0.000179 \\
\hline $36.71-36.96$ & 0 & 1 & 10 & 0 & 0 & 12 & 1 & 24 & $52,966,344$ & 0.0000453 \\
\hline $51.02-51.27$ & 1 & 1 & 13 & 0 & 0 & 59 & 3 & 76 & $105,196,187$ & 0.0000722 \\
\hline $133.18-133.43$ & 0 & 0 & 10 & 0 & 0 & 59 & 1 & 70 & $4,720,630$ & 0.00148 \\
\hline $192.70-192.95$ & 0 & 5 & 5 & 0 & 0 & 31 & 3 & 44 & $22,438,819$ & 0.000196 \\
\hline $252.80-253.05$ & 0 & 1 & 10 & 0 & 0 & 20 & 3 & 34 & $50,699,071$ & 0.0000671 \\
\hline $336.50-336.75$ & 0 & 1 & 10 & 0 & 0 & 20 & 1 & 32 & $5,834,451$ & 0.000548 \\
\hline $375.15-375.40$ & 0 & 2 & 2 & 0 & 0 & 31 & 18 & 71 & $2,137,962$ & 0.00332 \\
\hline $424.85-425.10$ & 0 & 31 & 3 & 0 & 0 & 59 & 12,600 & 12,693 & $4,446,313$ & 0.285 \\
\hline $503.45-503.70$ & 3 & 117 & 31 & 0 & 0 & 31 & 12,600 & 12,779 & $6,823,387$ & 0.187 \\
\hline
\end{tabular}

Data are not presented here for counts of methanogenic bacteria, as they have not yet grown sufficiently for their numbers to be calculated. In previous work (Cragg et al., 1990), methanogens have taken more than 18 months to enrich, with two subcultures, and that period has not yet elapsed since these samples were obtained. Preliminary data (headspace methane analysis) indicate the presence of methanogens between 0.825 and 2.59 mbsf.

Compared to all other MPN results the nitrate-reducers and the acetogens showed much reduced changes in bacterial numbers with depth. This suggests that the growth medium employed was probably not sufficiently selective for the intended populations and should be improved in the future.

The different groups of anaerobic bacteria identified by MPN enrichment can be added together to give some estimate of the total culturable anaerobic population, although the different types are not totally exclusive (e.g., nitrate and sulfate reducers are specialized heterotrophs, Table 4). The total anaerobic culturable population, expressed as a percentage of the direct count, provides a measure of the viability of the anaerobic bacteria. Viabilities are low, $(0.000045 \%-$ $0.57 \%)$, and cover a wide range $(12,600$-fold). Highest values occurred in the top $10 \mathrm{~m}$ of the core and toward the base at 425 and 503.5 mbsf (Table 4).

\section{Potential Activities}

Rates of activity obtained in this study should be regarded as potential because we are, as yet, unable to assess the effects of storage (although this should be minimal, as samples were handled 3 weeks after collection) and pressure reduction effects encountered during core retrieval. Incubations were done at the average in-situ temperature but were not conducted at in-situ pressures.

$\left[{ }^{3} \mathrm{H}\right]$-thymidine incorporation into bacterial DNA occurs primarily in the upper section of the core (Fig. 6). Maximum rate was $0.48 \mathrm{pmol} / \mathrm{cm}^{3} / \mathrm{d}$ at $0.225 \mathrm{mbsf}$, declining logarithmically to zero at $5.72 \mathrm{mbsf}$. Trace levels of activity $\left(0.0004\right.$ and $\left.0.0001 \mathrm{pmol} / \mathrm{cm}^{3} / \mathrm{d}\right)$ were observed at 23.72 and 78.92 mbsf, respectively.

Sulfate reduction is also concentrated in the upper 5-6 $\mathrm{m}$ of the core (Fig. 7A), with a maximum rate of $24.77 \mathrm{nmol} / \mathrm{cm}^{3} / \mathrm{d}$ at the shallowest depth $(0.125 \mathrm{mbsf})$, declining rapidly to $3.3 \mathrm{nmol} / \mathrm{cm}^{3} / \mathrm{d}$ at $0.775 \mathrm{mbsf}$ and then more gradually to $0.06 \mathrm{nmol} / \mathrm{cm}^{3} / \mathrm{d}$ at $5.52 \mathrm{mbsf}$. The maximum rate of sulfate reduction is low but comparable to pre- viously published rates for more productive sites such as inshore marine sites $\left(0.2-2800 \mathrm{nmol} / \mathrm{cm}^{3} / \mathrm{d}\right.$; Senior et al., 1982; Parkes and Taylor, 1985; Parkes and Buckingham, 1986), and also with rates from continental shelf surface sediments $\left(0.0001-46 \mathrm{nmol} / \mathrm{cm}^{3} / \mathrm{d}\right.$; Sorokin, 1962, Tsou et al., 1973; Goldhaber and Kaplan, 1975; Jørgensen, 1983; Parkes and Taylor, 1985; Edenborn et al., 1987; Cragg et al., 1990). Sulfate reduction is present at all depths to $424.9 \mathrm{mbsf}$ (Fig. 7B), although the rates are very low; between 12.62 and $424.9 \mathrm{mbsf}$ the average rate is only $1.7 \mathrm{pmol} / \mathrm{cm}^{3} / \mathrm{d}$. However between these depths there was a small increase in sulfate reduction rates at $78.72 \mathrm{mbsf}\left(3 \mathrm{pmol} / \mathrm{cm}^{3} / \mathrm{d}\right)$ and again toward the bottom of the core (Fig. 7B). Pore-water sulfate has a similar profile to that of sulfate reduction and declines rapidly from $18.55 \mathrm{mmol} / \mathrm{dm}^{3}$ at $0.125 \mathrm{mbsf}$ to $0.78 \mathrm{mmol} / \mathrm{dm}^{3}$ by $9.62 \mathrm{mbsf}$ (Fig. 7A). Although sulfate is found in all samples below $9.62 \mathrm{mbsf}$, the maximum concentration is only $0.92 \mathrm{mmol} / \mathrm{dm}^{3}$ (78.72 mbsf).

The depth profile of sulfate reduction rates is significantly correlated $(r=-0.755 ; p<0.002, n=21)$ with changes in the total pool of reduced sulfide. The relationship between sulfate reduction and each of the two pools of sulfide (AVS and PVS), however, is quite different. Over the first meter, rates of sulfate reduction significantly correlated $(r=0.991 ; p<0.001, n=4)$ with a similar decline in the concentration of AVS (Fig. 8). At the same time a significant negative correlation $(r=-0.925 ; p<0.05, n=4)$ was observed between the sulfate reduction rate and PVS concentration (Fig. 8). Maximum concentrations of both AVS and PVS are, however, much deeper in the sediment than sulfate reduction rates; AVS, $2.53 \mathrm{mmol} \mathrm{S} / \mathrm{dm}^{3}$ at $12.62 \mathrm{mbsf}$, and PVS, $33.30 \mathrm{mmol} \mathrm{S} / \mathrm{dm}^{3}$ at $36.73 \mathrm{mbsf}$, and there are considerable concentration changes with sediment depth. Most noticeably there are increases in both AVS and PVS at about 6 mbsf, between 36.7 and $131.7 \mathrm{mbsf}$, and toward the bottom of the core (Fig. 8). The average concentration of PVS $\left(21.29 \mathrm{mmol} \mathrm{S} / \mathrm{dm}^{3}\right)$ is very much higher than that of AVS $\left(0.97 \mathrm{mmol} \mathrm{S} / \mathrm{dm}^{3}\right)$.

Methanogenesis from $\mathrm{CO}_{2} / \mathrm{H}_{2}$ occurs principally in the top $1 \mathrm{~m}$ of the core with a mean rate of $0.55 \mathrm{nmol} / \mathrm{cm}^{3} / \mathrm{d}$ (Fig. 9). Maximum rates averaged $0.61 \mathrm{nmol} / \mathrm{cm}^{3} / \mathrm{d}$ between 0.325 and $0.825 \mathrm{mbsf}$. This is comparable to rates of $0.01-20 \mathrm{nmol} / \mathrm{cm}^{3} / \mathrm{d}$ found in the Baltic Sea (Lein et al., 1981), $0.2-1.0 \mathrm{nmol} / \mathrm{cm}^{3} / \mathrm{d}$ and $0.5-1.8 \mathrm{nmol} / \mathrm{cm}^{3} / \mathrm{d}$ in clean and organically enriched sea-loch sites (Parkes and Taylor, 1985 ), and $0.18 \mathrm{nmol} / \mathrm{cm}^{3} / \mathrm{d}$ on the Peru margin (Cragg et al., 1990). Below 1.65 mbsf, methanogensis rates were recorded at all depths to 424.9 mbsf, except 252.8 mbsf. Small increases of 0.124 and 


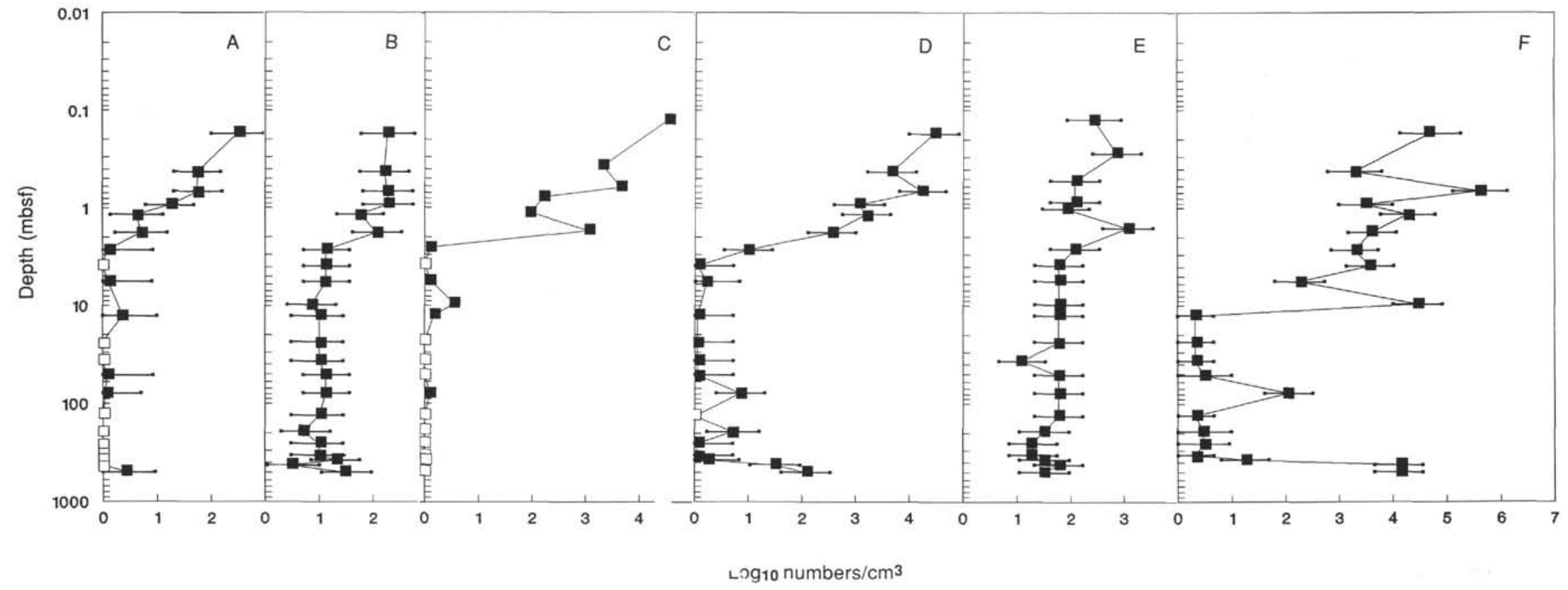

Figure 5. Depth distribution of the viable bacterial population to $517.90 \mathrm{mbsf}$, obtained using a most-probable-number technique. A. Aerobic ammonifiers. B. Nitrate reducers. C. Sulfate-reducers (acetate and lactate utilizing combined). D. Anaerobic ammonifiers. E. Acetogens. F. Heterotrophs (horizontal bars are $95 \%$ confidence limits, and open symbols indicate a zero count). 


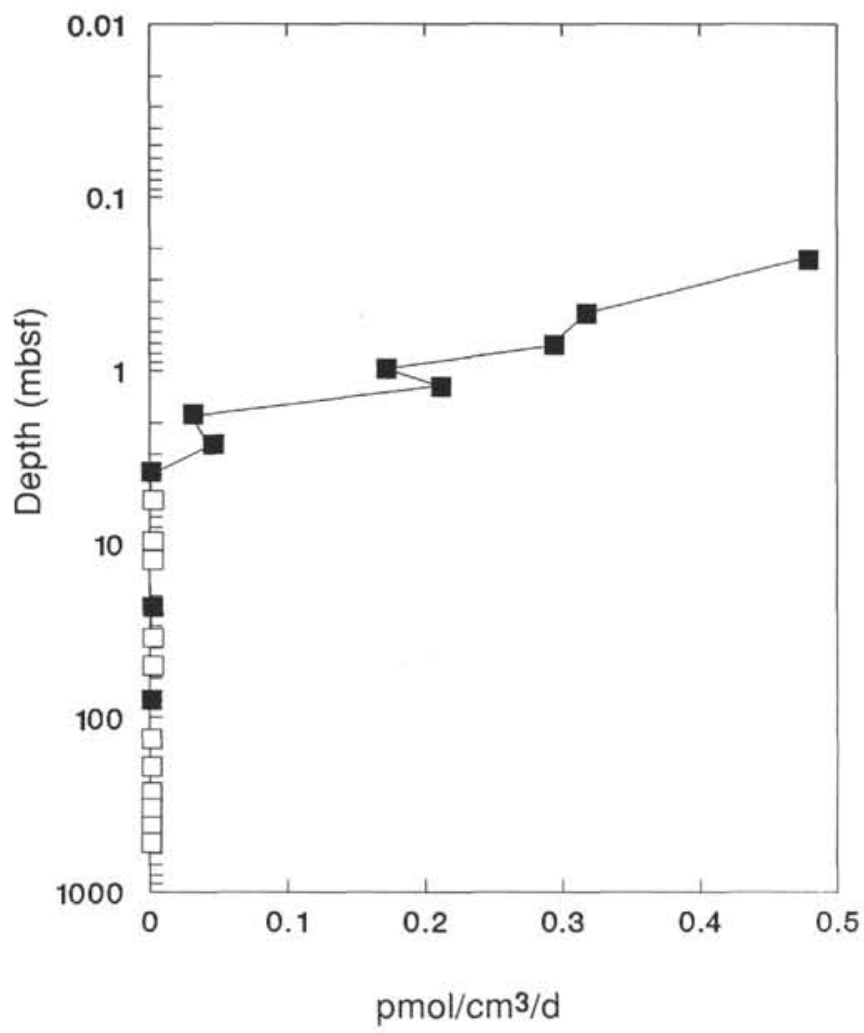

Figure 6. Depth distribution of rates of $\left[{ }^{3} \mathrm{H}\right]$ - thymidine incorporation into bacterial DNA ( $\mathrm{pmol} / \mathrm{cm}^{3} / \mathrm{d}$ ), to $425 \mathrm{mbsf}$. Open symbols indicate no incorporation detected.

$0.094 \mathrm{nmol} / \mathrm{cm}^{3} / \mathrm{d}$ were observed at two depths, 2.59 and 78.77 mbsf, respectively. Pore-water methane concentrations are negligible to $5.82 \mathrm{mbsf}$ and then increase sharply to $0.93 \mu \mathrm{mol} / \mathrm{cm}^{3}$ before declining to a mean of $0.26 \mu \mathrm{mol} / \mathrm{cm}^{3}$ down to $375.4 \mathrm{mbsf}$ (Fig. 9). The large increase in methane concentrations below $375.4 \mathrm{mbsf}$, to $1.76 \mu \mathrm{mol} / \mathrm{cm}^{3}$, is due to thermogenic gas production (Ingle, Suyehiro, von Breymann, et al., 1990).

\section{DISCUSSION}

Direct microscopic determination of intact bacterial cells clearly shows that significant populations of bacteria were present in all samples analyzed (Fig. 3). In addition, a portion of this population was dividing even in the deepest sample, 518 mbsf (Fig. 4). Despite the overall logarithmic decrease in bacteria with increasing sediment depth, there are several discrete increases in bacterial numbers, which continue over considerable depth intervals (Fig. 3). These increases are at 10, 50, and $200 \mathrm{mbsf}$, and there is also an indication of an increase in bacteria toward the bottom of the core. This situation is very different from the generally accepted view that the bulk of bacterial changes within sediments occur within the top $10 \mathrm{~cm}$, and that below $1 \mathrm{~m}$, changes in bacterial populations are extremely limited (Rheinheimer, 1985). These increases in bacterial concentrations are seen more clearly when the data are averaged over each $25-\mathrm{cm}$ whole-round core section (Fig. 10), and a close positive relationship between total bacteria and numbers of dividing cells is also apparent.

Although the acridine orange epifluorescence technique does not discriminate between living, dormant, or possibly recently dead cells, the presence of dividing cells is an index of growth and hence viability (Hagstrøm et al., 1979). The frequency of dividing cells can be used to estimate bacterial growth rates in pelagic environments, but its application in sediments is more problematical as divided cells may remain attached or in close proximity for long periods of time after division, thus making accurate estimation of growth difficult (Newell and Fallon, 1982; Fallon et al., 1983). Growth studies on stimulated population of sediment bacteria (Getliff, 1991), including samples from this core, (Getliff et al., this volume) have, however, clearly demonstrated that increases in numbers of dividing cells coincide with midlogarithmic growth phase, and that subsequently numbers of dividing cells rapidly decrease. These data, coupled with the clear increases in numbers of dividing cells at specific depth intervals, strongly suggest that bacteria are actually growing in the sediment rather than just surviving, as the mere survival of dividing cells from the more active surface layers cannot explain the observed profile (Fig. 4). Similarly, the increases in bacterial numbers in deeper layers cannot be explained by the mixing of surface sediment (with high bacterial concentrations) into deeper sediment layers as a result of smearing along the core liner during coring, as the sediment layers immediately above actually have lower bacterial populations (Figs. 3 and 10). Although massive mixing of sediment during coring could produce an artificial bacterial profile, it is evident from the good core recovery $(99 \%)$ and from all shipboard measurements that coring disturbance was minimal and individual horizons excellently preserved (Ingle, Suyehiro, von Breymann, et al., 1990). In addition, the analysis of bacterial concentrations horizontally across a sectioned whole-round core showed no significant differences in bacterial numbers between sediment adjacent to the core liner and that toward the center of the core (unpubl. data). As a further precaution, however, samples for bacterial counts were only taken from the center of a whole-round core.

The profile of bacteria with depth appears to fall into three broad sections: (1) a top section $(0-6 \mathrm{~m})$ where bacterial numbers are decreasing rapidly, (2) a middle section $(6-375 \mathrm{~m})$ where the rate of decrease is less and there are some distinct increases in bacteria, and (3) a bottom section ( $375-518 \mathrm{~m}$ ) where bacterial numbers consistently increase (Fig. 10; this figure includes direct counts for the deepest sample, not included in Figure 3 as this was a "fresh" sample, see Results). Numbers of dividing cells exhibit a similar profile, but this is complicated by the absence of dividing cells in some samples below $1 \mathrm{~m}$. After a rapid decrease in dividing cells over the topmost $2 \mathrm{~m}$, they are either below the detection limit or continue to be present as a constant proportion (average $4.8 \%$ ), of the total bacterial population (Figs. 4 and 10). In this section there were therefore distinct periods of bacterial growth $(10,50,200$, and below $375 \mathrm{mbsf})$ that correspond with increases in the total bacterial population (Figs. 3, 4, and 10). Between 375 and $518 \mathrm{mbsf}$, although numbers of dividing cells remain relatively constant at $2.5 \times 10^{5} / \mathrm{cm}^{3}$, they represent an elevated proportion of the total population (average $6.25 \%$ ). Percentage viabilities also increase over this depth range (Table 4).

Despite the overall decrease in the bacterial population with sediment depth, the populations in the deeper layers are still very significant below 300 mbsf, representing, on average, $5 \%$ of the near-surface population (average for the top $25 \mathrm{~cm}$; Table 4) and even for the deepest sample at $518 \mathrm{mbsf}, 4 \%$ of the near-surface population. These values are slightly higher than those found previously for deep sediment layers from the Peru Margin (1\% at 80 mbsf, Leg 112; Cragg, et al., 1990). However, the average surface bacterial population $(0-25 \mathrm{~cm})$ in Peru sediments $\left(1.37 \times 10^{9} / \mathrm{cm}^{3}\right)$ is significantly larger than that reported here, $\left(5.29 \times 10^{8} / \mathrm{cm}^{3}\right)$. Such significant bacterial populations must have profound effects on continued diagenetic reactions within these sediments, as a source of energy would be required to maintain these populations.

\section{Viable Bacterial Populations}

Bacteria were cultured, in various media, from all depths sampled (Figs. 5A-5F). Depth profiles of viable bacteria generally have a distribution similar to the total bacterial population (Fig. 3), with a 
$\mathrm{SO}_{4}$ reduction $\mathrm{nmol} / \mathrm{cm}^{3} / \mathrm{d}$

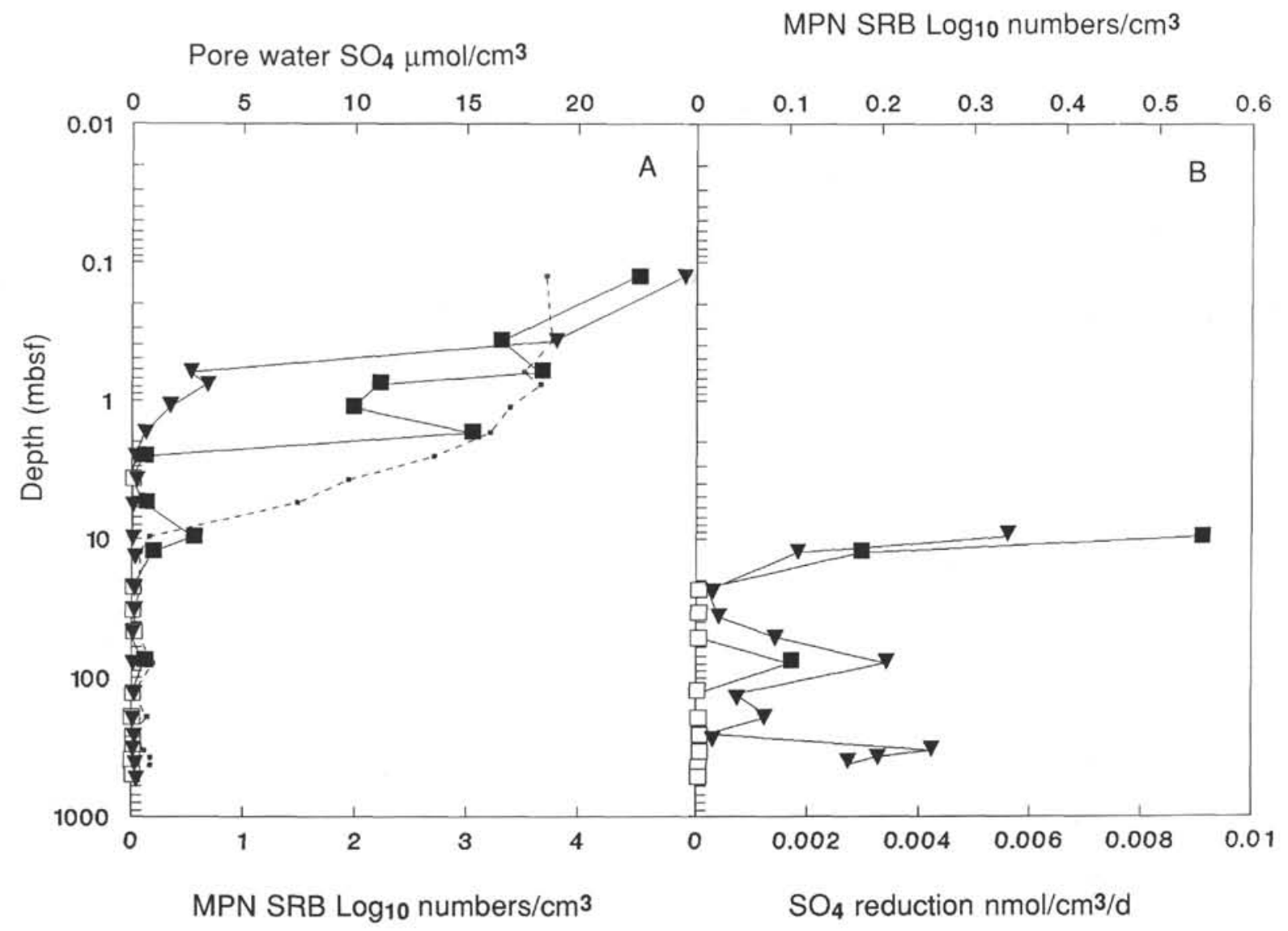

Figure 7. Depth distribution of pore-water sulfate $(\mathbf{m - - -}), \mu \mathrm{mol} / \mathrm{cm}^{3}$, potential sulfate reduction activity $(\mathbf{\nabla}-\mathbf{\nabla}), \mathrm{nmol} / \mathrm{cm}^{3} / \mathrm{d}$, and MPN viable count of sulfate-reducing bacteria (scales (pore-water sulfate not included).

rapid decrease over the top $6 \mathrm{~m}$. There was a trend of bacterial succession with increasing sediment depth, based on the use of the expected sequence of respiratory terminal electron acceptors: oxygen, nitrate, sulfate, carbon dioxide (Parkes and Senior, 1988). This is reflected in the depth at which the initial high-surface populations reached zero or minimum values. These populations are aerobic ammonifiers (3 mbsf, Fig. 5A), nitrate-reducing bacteria (3 mbsf, Fig. 5B), sulfate-reducing bacteria ( $3 \mathrm{mbsf}$, but with significant increases deeper down, Fig. 5C), anaerobic ammonifiers (4 mbsf, Fig. 5D), acetogens (4 mbsf, Fig. 5E); and finally, anaerobic heterotrophic bacteria that do not require an external respiratory electron acceptor, 6 mbsf (Fig. 5F). In the middle section (6-375 mbsf), as for the total bacterial population, numbers of viable bacteria are more constant except for a few marked increases at specific depths. For viable counts these are at $10 \mathrm{mbsf}$ (aerobic ammonifiers, sulfate-reducing bacteria, and anaerobic heterotrophic bacteria), $80 \mathrm{mbsf}$ (aerobic and anaerobic ammonifiers, sulfate-reducing bacteria, and anaerobic heterotrophic bacteria), and below $375 \mathrm{mbsf}$ (aerobic and anaerobic ammonifiers, nitrate-reducing bacteria, acetogens, and anaerobic heterotrophic bacteria).

Viable counts must be interpreted with caution as, in addition to the potential for contamination, they represent such a small proportion of the total bacterial population (Table 4), and the bacteria selected in rich media may not be representative of those actually active in situ (Parkes and Taylor, 1985). However the strong positive correlation ( $p$ $<0.002, n=15$ ) between numbers of viable sulfate-reducing bacteria and both sulfate reduction rates and the pore-water sulfate concentration (Figs. 7A and 7B), demonstrates that this MPN is a realistic index of the presence of specific types of bacteria within the sediment. This demonstration, together with our previous data showing positive relationships between MPN viable counts and activity within deep sediment layers (Parkes et al., 1990), suggests that all the MPN series probably enriched a small, but meaningful, subset of the natural bacterial population, and that contamination was not a problem.

The general similarity of the MPN profiles is not surprising, as they are all different types of heterotrophic bacteria. Although bacteria able to utilize a complete range of electron acceptors $\left(\mathrm{O}_{2}\right.$ to $\left.\mathrm{CO}_{2}\right)$ were isolated, apart from the strict anaerobes, their in-situ metabolism is likely to be quite different, or they may be dormant. For example, the common capacity of facultative anaerobic heterotrophic bacteria to reduce nitrate would explain the presence of nitrate-reducing bacteria within a sediment that is unlikely to contain nitrate except very close to the sediment surface (as sulfate is very rapidly removed below $1 \mathrm{mbsf}$, Fig. 7A). The increase in five of the six different viable counts after 375 mbsf (Figs. 5A-5F) was very surprising, but it is extremely unlikely that this was caused by contamination during coring as the sediment above had, generally, much lower bacterial populations. Also, the increase in the total viable anaerobic population corresponds to an increase in the total bacterial population (Fig. 10), and the average viability of the deepest layers ( $375-518 \mathrm{mbsf}$ ) was considerably higher than the middle section, and similar to the average viability of the top $6 \mathrm{~m}$ of sediment (Table 4). Overall viabilities of anaerobic bacteria are approximately a factor of 10 times higher than those observed in deep sediment layers in Peru $(0.0000087 \%-0.03 \%$ over the top 80 mbsf; Cragg, et al., 1990, and Table 4). This may 
PVS $\mu \mathrm{mol} \mathrm{S}-/ \mathrm{cm}^{3}$

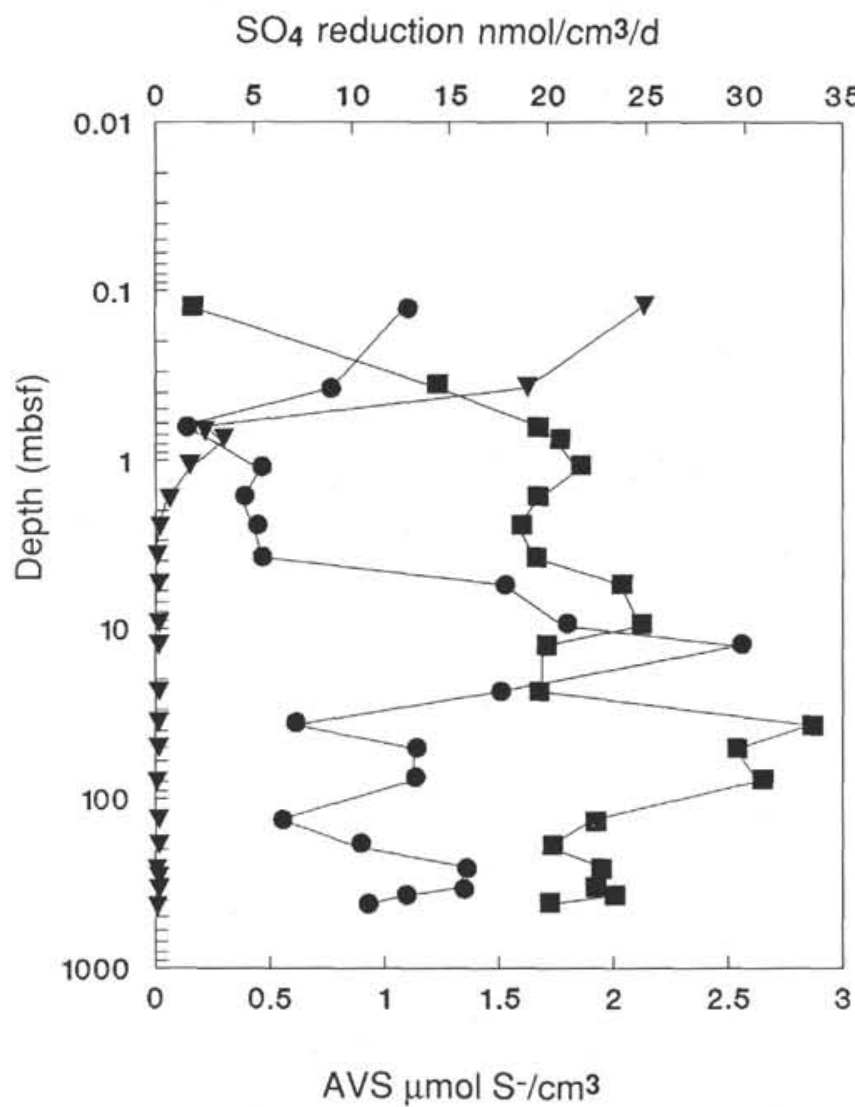

Figure 8. Depth distribution of concentrations of acid-volatile sulfide (AVS:

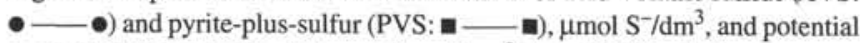
rates of sulfate reduction $(\mathbf{\nabla}-\mathbf{\nabla}) \mathrm{nmol} / \mathrm{cm}^{3} / \mathrm{d}$, to $517.90 \mathrm{mbsf}$.

reflect real differences in the bacterial populations at the two sites, however there are some experimental differences between these studies. (Storage time was reduced for Japan [Japan sediments3 weeks, Peru sediments- 2 months], and there were improvements in storage conditions, handling, and media).

\section{Rates of Bacterial Activity}

Bacterial activity within intact subcores has profiles similar to those of the bacterial populations, high activity within surface sediments decreasing rapidly down to 3 mbsf (Figs. 11A and 11B). Anaerobic sulfate reduction correlated significantly with both the pore-water sulfate profile (+ve, $p<0.05$; Fig. 7A), and the total pool of reduced sulfide (-ve, $p<0.002$; Fig. 8 ). The negative correlation between sulfate reduction and the total reduced sulfide pool is due to reoxidation of the bulk of the sulfide near the sediment surface (Jørgensen, 1982), where rates of sulfate reduction are maximum (Fig. 7A), and the sediment is "open" due to bioturbation and physical disturbance. Metal sulfides build up below this zone but rates of sulfate reduction are then relatively low. Sulfate reduction is present at all depths and resulted in the accumulation of significant concentrations of reduced sulfide species (Fig. 8). The end products of active sulfate reduction varied considerably down the core. Initially AVS is the dominant product although this rapidly decreases and PVS production increases, its rate of production following closely the removal of pore-water sulfate (Figs. 12A and 12B). Changes in the total pool of both AVS and PVS near the sediment surface are similar to those
$\mathrm{CH}_{4}$ production $\mathrm{nmol} / \mathrm{cm}^{3} / \mathrm{d}$

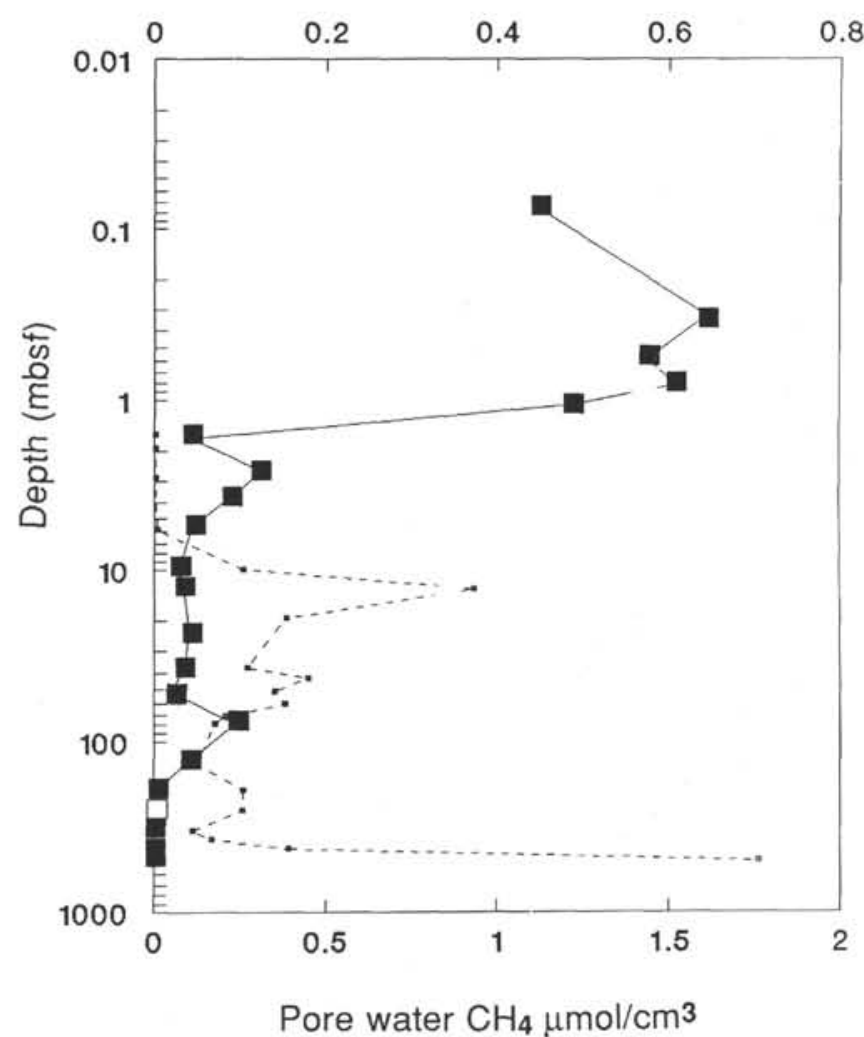

Figure 9. Depth distribution of sediment methane concentrations (- . - $)$ $\mu \mathrm{mol} / \mathrm{cm}^{3}$ and potential rates of methane production (- $) \mathrm{nmol} / \mathrm{cm}^{3} / \mathrm{d}$ to 517.90 mbsf. Open symbols indicate zero-value data.

observed for the above sulfate reduction rates; AVS is high near the sediment surface and then decreases with depth, while PVS has the opposite trend with depth (Fig. 8). At approximately 6 and $80 \mathrm{mbsf}$ and toward the bottom of the core, both AVS and PVS concentrations increase, corresponding with increases in the rate of sulfate reduction (Figs. 7B, 8, and 13).

Methanogenesis from $\mathrm{CO}_{2} / \mathrm{H}_{2}$, although high near the sediment surface, increases with depth to reach highest rates immediately beneath the maximum rate of sulfate reduction (Fig. 11A). Despite reasonable rates of methanogenesis, $\left(0.55 \mathrm{nmol} / \mathrm{cm}^{3} / \mathrm{d}\right)$, no methane gas is present in the upper sediment $(0-5 \mathrm{mbsf} ;$ Fig. 9$)$. The methane produced must have, therefore, diffused out of the sediment, or have been consumed within the sediment by bacterial activity. Methanogenesis subsequently decreases rapidly, and after $1.65 \mathrm{mbsf}$ only low rates were detected. Below $5.6 \mathrm{mbsf}$, however, these low rates were accompanied by the presence of methane gas (Fig. 13). Subsequent increases in methanogenesis appear to be loosely associated with increases in methane gas concentrations higher in the sediment. The marked increase in methanogenesis at about $80 \mathrm{mbsf}$, for example, produced a small increase in methane gas concentration immediately above it (Figs. 9 and 13). With only one exception, low rates of methanogenesis were present at all depths.

Rates of thymidine incorporation into DNA have been used as a quantitative measure of bacterial growth (Moriarty, 1990). Within sediments, however, thymidine can be rapidly metabolized as an energy source in addition to direct assimilation into DNA (Staley and Konopka, 1985; Hollibaugh, 1988; Brittain and Karl, 1990), which makes accurate estimation of growth rates difficult. Hence thymidine 


\section{Pore water $\mathrm{CH}_{4} \mu \mathrm{mol} / \mathrm{cm}^{3}$}

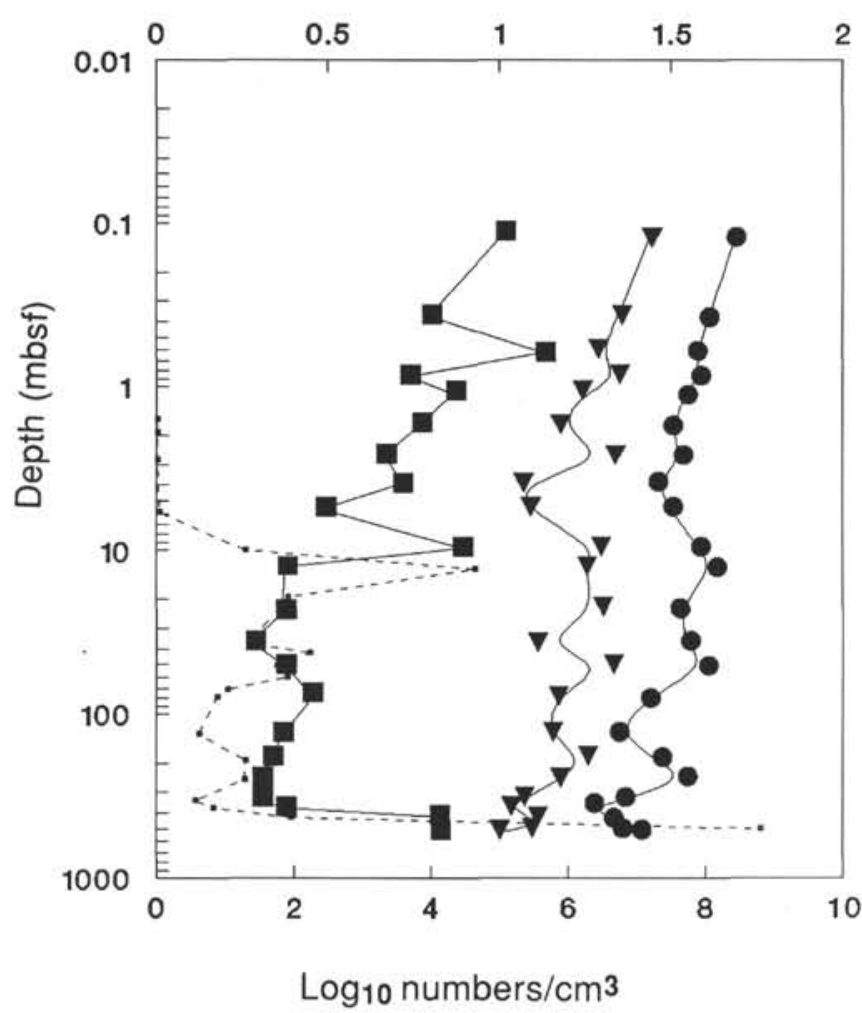

Figure 10. Depth distribution of bacterial populations, total bacteria ( $-\bullet)$, numbers of dividing and divided cells $(\mathbf{\nabla}-\mathbf{\nabla})$, both averaged for $25-\mathrm{cm}$ depth sections (zero data for dividing cells assigned the value of the detection limit, $\left.10^{5} / \mathrm{cm}^{3}\right)$, total anaerobic viable count (- bacteria $/ \mathrm{cm}^{3}$, and methane (*...) $\mu \mathrm{mol} / \mathrm{cm}^{3}$ to $517.90 \mathrm{mbsf}$. Data for total bacteria and dividing cells are presented with a computer-generated curve of best fit.

incorporation rates are used here only as an index of bacterial growth. The depth profile of thymidine incorporation was very similar to those of other activity measurements, being high near the sediment surface and decreasing rapidly to low rates by 3 mbsf (Fig. 11A). This correlates with the distribution of numbers of dividing bacteria $(r=0.63$; $p<0.02, n=15,0-80 \mathrm{mbsf}$ ).

\section{General}

Even in the deepest sediment layers where rates of bacterial activity are very low, there is a good agreement between the profiles of the totally independent measurements of activity (Fig. 11B). For example, the only two positive rates of thymidine incorporation below $5.72 \mathrm{mbsf}$ correspond with either increases in methanogenesis (23.7 mbsf) or methanogenesis and sulfate-reduction ( $78.9 \mathrm{mbsf}$ ). Changes in bacterial activity with sediment depth are reflected in a similar distribution of viable total anaerobic heterotrophic bacteria (Figs. 7, 11A, and 11B), although the increase in the viable bacterial population below $375 \mathrm{mbsf}$ is particularly pronounced compared to increases in activities. This may reflect the lack of an appropriate activity measurement for these deep bacteria.

Sulfate reduction is quantitatively more important than methanogenesis in the top $10 \mathrm{~m}$ of sediment (average rate for sulfate reduction and methane production was 5.2 and $0.31 \mathrm{nmol} / \mathrm{cm}^{3} / \mathrm{d}$ respectively). These results, therefore depict the standard profile within marine sediments with sulfate-reducing bacteria out-competing methanogenic bacteria for common growth substrates. Thus sulfate reduction is both closer to the supply of organic matter at the sediment surface and quantitatively dominant over methanogenesis. In addition to this competitive relationship there seems, however, to be a more subtle positive interaction.

Threshold concentrations of sulfate at which sulfate reduction can no longer effectively compete against methanogenesis are between 5 and $10 \mathrm{mmol} / \mathrm{dm}^{3}$ for surface sediments (Westrich, 1983). Hence as sulfate reduction decreases from around $18 \mathrm{mmol} / \mathrm{dm}^{3}$ sulfate in these sediments (Fig. 7), some other factor must be limiting, probably organic carbon. The increase in sulfate reduction at $6 \mathrm{mbsf}$ coincides exactly with the first appearance of dissolved methane (Fig. 13), and this small secondary peak in sulfate reduction may be due to the use of methane as an organic substrate. Secondary peaks in sulfate reduction associated with anaerobic methane oxidation have been demonstrated previously (Iversen and Jørgensen, 1985), and anaerobic methane oxidation was also thought to be important in determining the bacterial profiles in the subsurface sediments from Peru (Parkes et al., 1990). The subsequent decrease and continued low levels of sulfate reduction is probably the result of sulfate limitation, as the sulfate concentration decreases rapidly to less than $1 \mathrm{mmol} / \mathrm{dm}^{3}$ by $10 \mathrm{mbsf}$, and hence methane gas concentrations increase due to continued methanogenesis (Fig. 13).

The increase in the total bacterial population, total anaerobic heterotrophs, bacterial viability (Table 4) and the small peak in sulfate reduction rates (Fig. 7B) below $375 \mathrm{mbsf}$, all coincide with a large increase in methane (Fig. 9) and other hydrocarbon gases (up to C5) from geothermal sources (Ingle, Suyehiro, von Breymann, et al., 1990). Although there is also an increase in organic carbon toward the bottom of the core, this increase does not occur until 475 mbsf (Ingle, Suyehiro, von Breymann, et al., 1990), some $50 \mathrm{~m}$ below the first increase in heterotrophic bacteria (Figs. 10 and 14). It seems highly likely that the increase in bacterial populations and activities is a response to the rise in methane concentrations, or some other component of the thermogenic gas, as no other chemical change was detected within this depth horizon. Higher in the core there is also an association of elevated bacterial populations with increases in methane gas, which is presumably biogenic in origin (Fig. 10). For example, between 12.6 and 503 mbsf there is a significant $(p<0.05, n=$ 12) positive relationship between numbers of total anaerobic viable bacteria and methane gas concentrations. It is unclear what controls changes in rates of methanogenesis below its subsurface maximum, and hence methane concentrations, as there is no significant relationship between methanogenesis and organic carbon ( $0-425 \mathrm{mbsf}$, Fig. 14). The bioavailability of the organic carbon, however, may be much more important than its absolute concentration (Parkes et al., 1990). Cyclical palaeoceanographic productivity and bottom-water oxygen changes in the Sea of Japan thought to be intimately related to the cyclical light and dark bands within this sediment (Ingle, Suyehiro, von Breymann, et al., 1990; and others, this volume), are likely to have resulted in fluctuations in the bioavailability of the organic carbon deposited and hence in both the size and persistence of bacterial populations that subsequently developed. Indeed the distribution of dividing cells between light and dark bands (K. Folmi, pers. comm., 1991) is significant $(p<0.02)$, with low numbers of dividing cells being strongly associated with light bands.

\section{SUMMARY}

The sediments studied have characteristic bacterial profiles in the top 6 mbsf, with high, but rapidly decreasing numbers of total and dividing bacteria, and populations of different types of viable heterotrophic bacteria, which are highly correlated with potential rates of bacterial activity. Rates of anaerobic sulfate reduction, and $\left[{ }^{3} \mathrm{H}\right]-$ thymidine incorporation into bacterial DNA are high in the surface sediments and decrease rapidly down to $3 \mathrm{mbsf}$. Sulfate reduction is quantitatively more important than methanogenesis from $\mathrm{CO}_{2} / \mathrm{H}_{2}$, which peaks below the maximum in sulfate reduction. Consistent with 
$\mathrm{SO}_{4}$ reduction $\mathrm{nmol} / \mathrm{cm}^{3} / \mathrm{d} \quad \mathrm{SO}_{4}$ reduction $\mathrm{nmol} / \mathrm{cm}^{3} / \mathrm{d}$

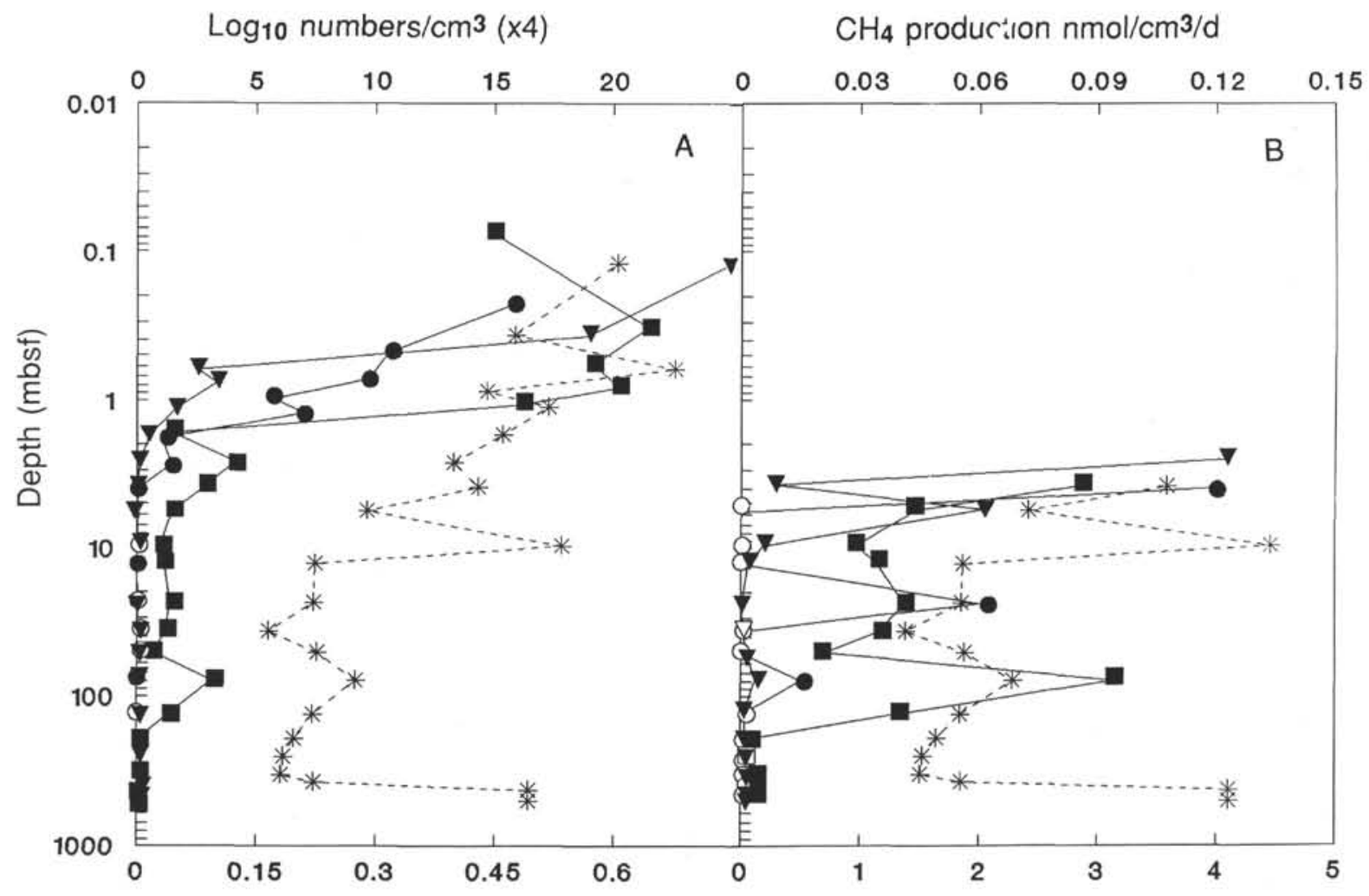

Thymidine incorporation $\mathrm{pmol} / \mathrm{cm}^{3 / \mathrm{d}} \quad$ Thymidine incorporation $\mathrm{fmol} / \mathrm{cm} 3 / \mathrm{d}(\mathrm{x} 10)$

\section{$\mathrm{CH}_{4} \mathrm{nmol} / \mathrm{cm}^{3} / \mathrm{d}$}

\section{$\log _{10}$ numbers $/ \mathrm{cm}^{3}$}

Figure 11. Similarity of the distribution of bacterial activity and viable bacterial populations with sediment depth, sulfate reduction $(\boldsymbol{\nabla}-\mathbf{\nabla})$ $\mathrm{nmol} / \mathrm{cm}^{3} / \mathrm{d}$, methanogenesis (- $\mathrm{nmol} / \mathrm{cm}^{3} / \mathrm{d}$, thymidine incorporation into DNA $(\bullet-\cdots) \mathrm{pmol} / \mathrm{cm}^{3} / \mathrm{d}$, and log total anaerobic viable count (*——) bacteria/ $\mathrm{cm}^{3} \times 4$ (A) to $517.90 \mathrm{mbsf}$ and $(\mathbf{B})$ between 9.60 and $517.90 \mathrm{mbsf}$ with expanded scales (thymidine incorporation $\mathrm{fmol} / \mathrm{cm}^{3} / \mathrm{d} \times 10 ; \log$ total anaerobic viable count - bacteria/ $\mathrm{cm}^{3}$ ). Open symbols indicate zero-value data.

these activities is the removal of pore-water sulfate, methane gas production and accumulation of reduced sulfide species. Below $6 \mathrm{mbsf}$ the rate of decrease in bacterial populations declines and there is also some distinct increases in both bacterial populations and bacterial activities that continue over considerable depth intervals (Figs. 10 and 11). Most dramatic is the large and significant increase in total heterotrophic bacteria below 375 mbsf, which corresponds to an increase in the total bacterial population, bacterial viability, a small increase in potential rates of sulfate reduction, and the presence of thermogenic methane and other hydrocarbon gases. Bacterial distributions seem to be controlled by the availability of terminal electron acceptors (e.g., sulfate), the bioavailability of organic carbon, which may be related to the dark/light cycles within the sediment, and methane gas, both biological and geothermal. Significant bacterial populations are present even in the deepest samples (518 mbsf, approximate age 4.3 Ma; Ingle, Suyehiro, von Breymann, et al., 1990) and must have a profound effect on continued diagenetic reactions within the sediment, as a source of energy would be required to maintain these populations. The presence of thermogenic gases may provide an appropriate energy source and hence bacteria may continue to be present and active much deeper than the sediments studied here. These results confirm and extend our previous results of bacterial activity within the deep sediments of the Peru Margin from Leg 112 (Cragg et al., 1990) and to our knowledge this is the first comprehensive report of the presence of active bacterial populations from sediment surface to depths in excess of 500 mbsf and over 4 m.y. old.

\section{ACKNOWLEDGMENTS}

We thank Joe Powers and Valerie Clark (ODP shipboard technicians) for assistance with pore-water samples and providing some chemical data, and all ODP personnel on the cat-walk and in the core reception laboratory for ensuring that we obtained the most useful samples. A significant amount of this research was conducted at the Dunstaffnage Marine Laboratory, Scotland, and we are grateful for the support and facilities provided. In particular we acknowledge the technical expertise of Shirley Vaughan, Mark James, and Janet Duncan for assistance in preparation of the MPN vials and for performing some of the pore-water chemistry and activity measurements. Kim Goodman (Bristol University) assisted with viable counts, Pam Baldero (Bristol University) drew Figure 1, and Margaret Griffiths (University of Wales, Cardiff) performed much of the AODC counting. We are grateful to Dererk Briggs (Bristol) and anonymous referees for constructive comments on an early manuscript, and Simon Bale (Bristol) for assistance with various computer graphics packages. This work was funded by a research grant 
(GST/02/420) from the Natural Environment Research Council, United Kingdom. We are grateful to the Ocean Drilling Program for allowing us to take samples from Leg 128.

\section{REFERENCES}

Balkwill, D. L., 1989. Numbers, diversity and morphological characteristics of aerobic chemoheterotrophic bacteria in deep subsurface sediments from a site in South Carolina. Geomicrobiol. J., 7:33-52.

Balkwill, D. L., Fredrickson, J. K., and Thomas, J. M., 1989. Vertical and horizontal variations in the physiological diversity of the aerobic chemoheterotrophic bacterial microflora in deep southeast coastal plain subsurface sediments. Appl. Environ. Microbiol., 55:1058-1065.

Belyaev, S. S., and Ivanov, M. V., 1983. Bacterial methanogenesis in underground waters. In Hallberg, R. (Ed.), Environ. Geochem. Ecol. Bull., 35:273-280.

Bianchi, A., 1986. Heterotrophic bacterial types surviving in the Quaternary and upper Pliocene sediments of the Mahakam Delta. C. R. Acad. Sci. Ser. 3, 303:449-451.

Brittain, A. M., and Karl, D. M., 1990. Catabolism of tritiated thymidine by aquatic microbial communities and incorporation of tritium into RNA and protein. Appl. Environ. Microbiol., 56:1245-1254.

Carmen, K. R., Dobbs, F. C., and Guckert, J. B., 1988. Consequences of thymidine catabolism for estimates of bacterial production: an example from a coastal marine sediment. Limnol. Oceanogr., 33:1595-1606.

Chapelle, F. H., and Lovley, D. R., 1990. Rates of microbial metabolism in deep coastal plain aquifers. Appl. Environ. Microbiol., 56:1865-1874.

Cline, J. D., 1969. Sectrophotometric determination of hydrogen sulfide in natural waters. Limnol. Oceanogr., 14:454-458.

Colwell, R. R., 1979. Enumeration of specific populations by the Most-Probable-Number (MPN) method. In Costerton, J. W., and Colwell, R. R. (Eds.), Native Aquatic Bacteria: Enumeration, Activity and Ecology: Philadelphia (ASTM), ASTM STP 695:56-61.

Cragg, B. A., Parkes, R. J., Fry, J. C., Herbert, R. A., Wimpenny, J.W.T., and Getliff, J. M., 1990. Bacterial biomass and activity profiles within deep sediment layers. In Suess, E., von Huene, R., et al.,Proc. ODP, Sci. Results, 112: College Station, TX (Ocean Drilling Program), 607-619.

Craven, D. B., and Karl, D. M., 1984. Microbial RNA and DNA synthesis in marine sediments. Mar. Biol., 83:129-139.

Cruikshank, R., Duguid, J. P., Marmion, B. P., and Swain, R.H.A., 1975. Medical Microbiology (Vol. 2): The Practice of Medical Microbiology (12th ed.): Edinburgh (Churchill Livingston).

Davis, J. B., 1967. Petroleum Microbiology: Amsterdam (Elsevier).

Edenborn, H. M., Silverberg, N., Mucci, A., and Sundby, B., 1987. Sulfate reduction in deep coastal marine sediments. Mar. Chem., 21:329-345.

Erlich, H. L., and Ghiorse, W. C. (Eds.), 1989. Special issue on deep subsurface microbiology. Geomicrobiol. J., 7.

Fallon, R. D., Newell, S. Y., and Hopkinson, C. S., 1983. Bacterial production in marine sediments: will cell-specific measures agree with whole system metabolism? Mar. Ecol. Prog. Ser., 11:119-127.

Fredrickson, J. K., Balkwill, D. L., Zachara, J. M., Shu-Mei, W. Li, Brockman, F. J., and Simmons, M. A., 1991. Physiological diversity and distributions of heterotrophic bacteria in deep Cretaceous sediments of the Atlantic coastal plain. Appl. Environ. Microbiol., 57:402-411.

Fry, J. C., 1988. Determination of biomass. In Austin, B. (Ed.), Methods in Aquatic Bacteriology: Chichester (Wiley), 27-72.

Getliff, J. M., 1991. Growth and productivity of shallow water and deep sea sediment bacteria [Ph.D. dissert.]. Univ. of Wales.

Goldhaber, M. B., and Kaplan, I. R., 1975. Controls and consequences of sulfate reduction rates in recent marine sediments. Soil Sci., 119:42-55.

Golterman, H. L., Clymo, R. S., and Ohnstad, M.A.M., 1978. Methods for Physical and Chemical Analysis of Freshwaters IBP8 (2nd ed.): Oxford (Blackwell).

Hagström, A., Larsson, U., Horstedt, P., and Normark, S., 1979. Frequency of dividing cells, a new approach to the determination of bacterial growth rates in aquatic environments. Appl. Environ. Microbiol., 37:805-812.

Hollibaugh, J. T., 1988. Limitations of the $\left[{ }^{3} \mathrm{H}\right]$ thymidine method for estimating bacterial productivity due to thymidine metabolism. Mar. Ecol. Prog. Ser., 43:19-30.

Hurley, M. A., and Roscoe, M. E., 1983. Automated statistical analysis of microbial enumeration by dilution series. J. Appl. Bacteriol., 55:159-164.
Ingle, J. C., Jr., Suyehiro, K., von Breymann, M. T., et al., 1990. Proc. ODP, Init. Repts., 128: College Station, TX (Ocean Drilling Program).

Iversen, N., and Jørgensen, B. B., 1985. Anaerobic methane oxidation rates at the sulfate-methane transition in marine sediments from Kattegat and Skagerrak (Denmark). Limnol. Oceanogr., 30:944-955.

Jannasch, H. W., and Taylor, C. D., 1984. Deep-sea microbiology. Ann. Rev. Microbiol., 38:487-514.

Jørgensen, B. B., 1978. A comparison of methods for the quantification of bacterial sulfate reduction in coastal marine sediments. I. Measurement with radiotracer techniques. Geomicrobiol. J., 1:11-28.

1982. Mineralization of organic matter in the seabed-the role of sulphate reduction. Nature, 296:643-645.

, 1983. Processes at the sediment/water interface. In Bolin, B., and Cook, R. B. (Eds.), The Major Biogeochemical Cycles and Their Interactions: Chichester (Wiley), 477-515.

Karl, D. M., 1982. Selected nucleic acid precursors in studies of aquatic microbial ecology. Appl. Environ. Microbiol., 44:891-902.

Krumbein, W. E., 1983. Microbial Geochemistry: Oxford (Blackwell).

Lein, A. Y., Namsaraev, G. B., Trotsyuk, V. Y., and Ivanov, M. V., 1981. Bacterial methanogenesis in Holocene sediments of the Baltic Sea. Geomicrobiol. J., 2:299-315.

Moriarty, D.J.W., 1990. Techniques for estimating bacterial growth rates and production of biomass in aquatic environments. Meth. Microbiol., 22:211-234.

Newell, S. Y., and Fallon, R. D., 1982. Bacterial productivity in the water column and sediments of the Georgia (U.S.) coastal zone: estimates via direct counting and parallel measurements of thymidine incorporation. Microbial Ecol., 8:333-346.

Oremland, R. S., Marsh, L. M., and Polcin, S., 1982. Methane production and simultaneous sulfate reduction in anoxic salt marsh sediments. Nature, 296:143-145.

Parkes, R. J., and Buckingham, W. J., 1986. The flow of organic carbon through aerobic respiration and sulfate reduction in inshore marine sediments. In Megusar, F., and Gantar, M. (Eds.), Proc. 4th Int. Symp. Microbial Ecol., $617-624$

Parkes, R. J., Cragg, B. A., Fry, J. C., Herbert, R. A., and Wimpenny, J.W.T., 1990. Bacterial biomass and activity in deep sediment layers from the Peru margin. Philos. Trans. R. Soc. London A, 331:139-153.

Parkes, R. J., and Senior, E., 1988. Multi-stage chemostats and other models for studying anoxic ecosystems. In Wimpenny, J.W.T. (Ed.), CRC Handbook of Laboratory Model Systems for Microbial Ecosystems: Boca Raton, FL (CRC) 1:51-72.

Parkes, R. J., and Taylor, J., 1985. Characterization of microbial populations in polluted marine sediments. J. Appl. Bacteriol., 59:155S-173S.

Pfennig, N., Widdel, F., and Truper, H. G., 1981. The dissimilatory sulfate-reducing bacteria. In Starr, M. P., Stolp, H., Truper, H. G., Balows, A., and Schlegal, H. G. (Eds.), The Prokaryotes (Vol. 1) New York (Springer-Verlag), 926-940.

Rheinheimer, G., 1985. Aquatic Microbiology (3rd ed.): Chichester (Wiley).

Rittenberg, S. C., 1940. Bacteriological analysis of some long cores of marine sediments. J. Mar. Res., 3:191-201.

Senior, E., Lindström, E. B., Banat, I. M., and Nedwell, D. B., 1982. Sulfate reduction and methanogenesis in the sediment of a salt marsh on the east coast of the United Kingdom. Appl. Environ. Microbiol., 43:987-996.

Sinclair, J. L., and Ghiorse, W. C., 1989. Distribution of aerobic bacteria, protozoa, algae, and fungi in deep subsurface sediments. Geomicrobiol. J., $7: 15-32$.

Sørensen, J., 1978. Denitrification rates in marine sediment as measured by the acetylene inhibition technique. Appl. Environ. Microbiol., $36: 139-143$.

Sørensen, J., and Jørgensen, B. B., 1987. Early diagenesis in sediments from Danish coastal waters: microbial activity and $\mathrm{Mn}-\mathrm{Fe}-\mathrm{S}$ geochemistry. Geochim. Cosmochim. Acta, 51:1583-1590.

Sorokin, Yu, I., 1962. Experimental investigation of bacterial sulfate reduction in the Black Sea using ${ }^{35}$ S. Microbiology, 31:329-335.

Staley, J. T., and Konopka, A., 1985. Measurement of in situ activities of nonphotosynthetic microorganisms in aquatic and terrestrial habitats. Ann. Rev. Microbiol., 39:321-346.

Tarafa, M. E., Whelan, J. K., Oremland, R. S., and Smith, R. L., 1987. Evidence for microbiological activity in Leg 95 (New Jersey Transect) sediments. In Poag, C. W., Watts, A. B., et al., Init. Repts. DSDP, 95: Washington (U.S. Govt. Printing Office), 635-640. 
Tsou, J. L., Hammond, D., and Horowitz, R., 1973. Interstitial water studies, Leg 15. Study of $\mathrm{CO}_{2}$ released from stored deep sea sediments: DSDPLeg 15. In Heezen, B. C., MacGregor, I. D., et al., Init. Repts DSDP, 20: Washington (U.S. Govt. Printing Office), 851-863.

Westrich, J. T., 1983. The consequences and controls of bacterial sulfate reduction in marine sediments [Ph.D. dissert.]. Yale Univ.

Whelan, J. K., Oremland, R., Tarafa, M., Smith, R., Howarth, R., and Lee, C., 1985. Evidence for sulfate-reducing and methane producing organisms in sediments from Sites 618, 619, and 622. In Bouma, A. H., Coleman, J. M.,
Meyer, A. W., et al., Init. Repts. DSDP, 96: Washington (U.S. Govt. Printing Office), 767-775.

ZoBell, C. E., 1958. Ecology of sulfate reducing bacteria. Prod. Mon., 22:12-29.

Date of initial receipt: 27 March 1991

Date of acceptance: 16 September 1991

Ms 127/128B-184

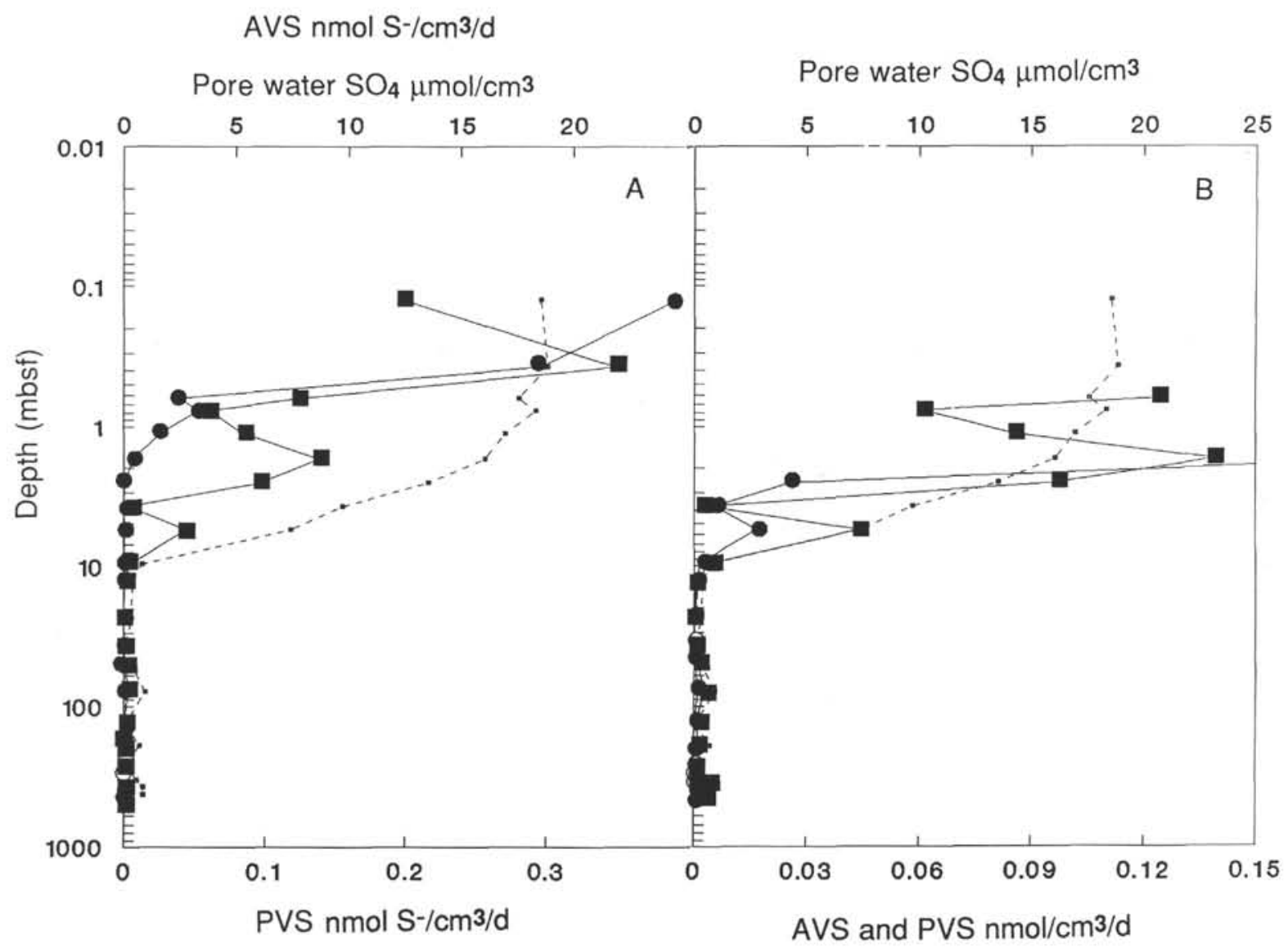

Figure 12. Relationship between different end products of sulfate reduction and removal of sulfate with sediment depth, sulfate reduction to AVS $(\bullet-\bullet)$ and PVS (- $-\mathrm{m}), \mathrm{nmol} / \mathrm{cm}^{3} / \mathrm{d}$, and pore-water sulfate concentrations $(*-\cdots) \mu \mathrm{mol} / \mathrm{cm}^{3}$ (A) to $517.90 \mathrm{mbsf}$ and (B) between 0.625 and 517.90 mbsf with expanded scales. Open symbols indicate zero-value data. 


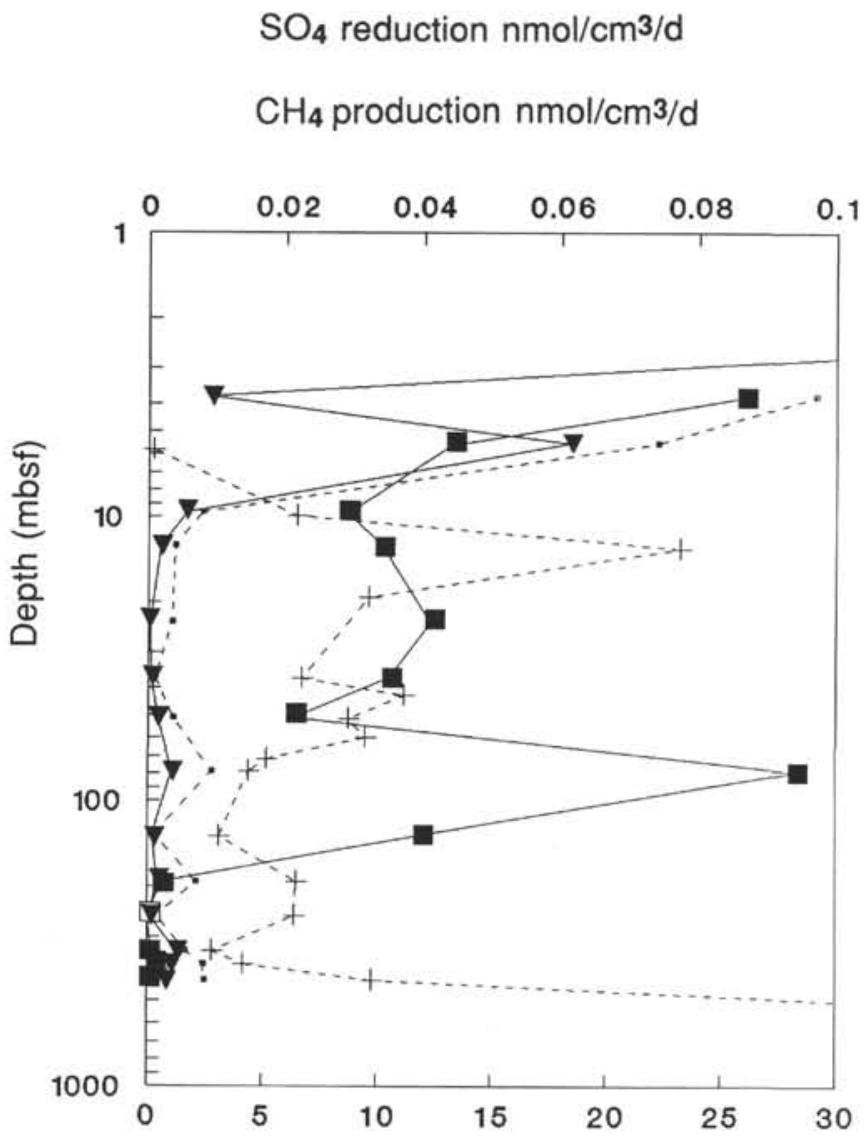

Pore water $\mathrm{SO}_{4}(x 3)$ and $\mathrm{CH}_{4}(\times 25) \mu \mathrm{mol} / \mathrm{cm}^{3}$

Figure 13. Relationship between potential rates of anaerobic bacterial activity and associated chemical changes within the sediment, sulfate reduction $(\mathbf{\nabla}-\boldsymbol{\nabla})$ $\mathrm{nmol} / \mathrm{cm}^{3} / \mathrm{d}$, methanogenesis (- $) \mathrm{nmol} / \mathrm{cm}^{3} / \mathrm{d}$, pore-water concentrations of sulfate $(\cdot-\cdot) \mu \mathrm{mol} / \mathrm{cm}^{3} \times 3$, and methane $(+\cdots+) \mu \mathrm{mol} / \mathrm{cm}^{3} \times 25$, between 3.77 and $517.90 \mathrm{mbsf}$. Open symbols indicate zero-value data.
Pore water $\mathrm{CH}_{4} \mu \mathrm{mol} / \mathrm{cm}^{3}$

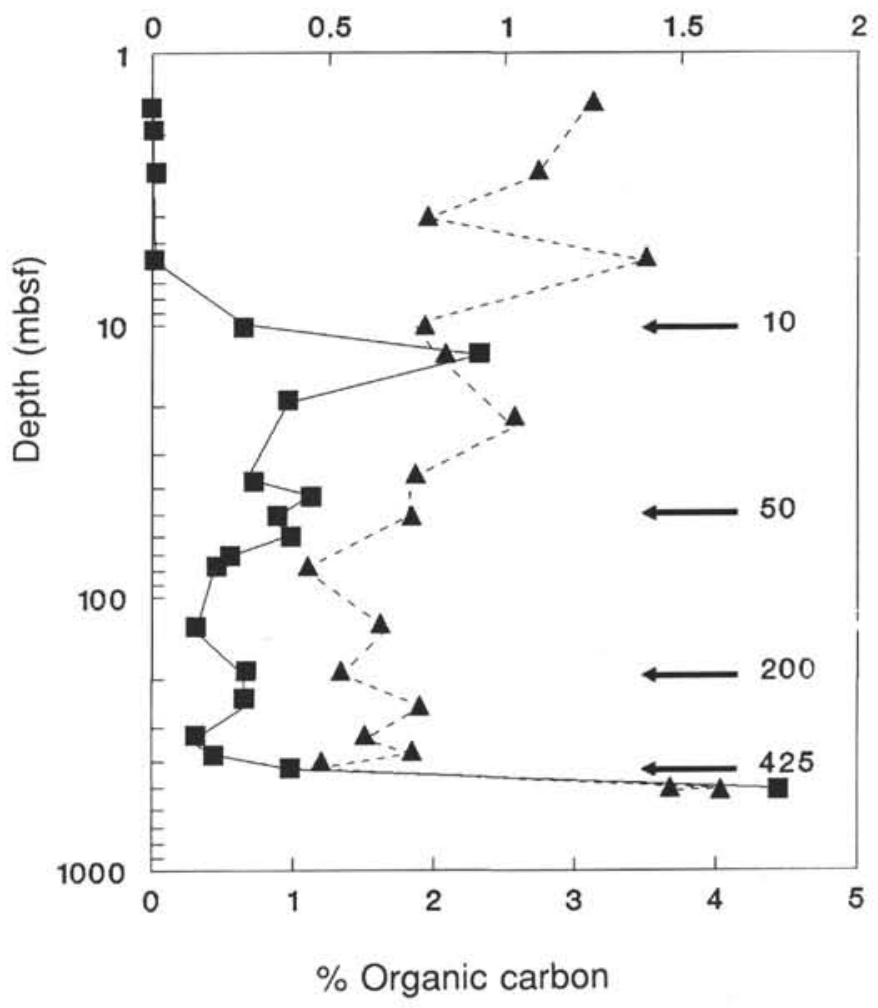

Figure 14. Relationship between increases in bacterial populations, methane and organic carbon with sediment depth, methane (- $\mu \mathrm{mol} / \mathrm{cm}^{3}$, and percentage organic carbon ( - . - - $\mathbf{\Delta}$ ) derived from shipboard data - Ingle, Suyehiro, von Breymann, et al. (1990). Arrowed numbers on the right of the graph indicate depths where bacterial populations increase. 